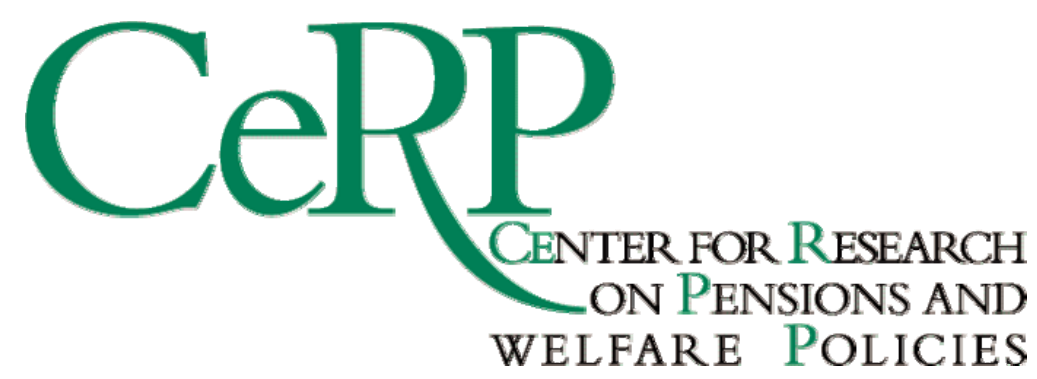

Working Paper 92/10

\title{
RETIREMENT CHOICES IN ITALY: WHAT AN OPTION VALUE MODEL TELLS US
}

\author{
Michele Belloni \\ Rob Alessie
}




\title{
Retirement choices in Italy: what an option value model tells us*
}

\author{
Michele Belloni ${ }^{\dagger} \quad$ Rob Alessie ${ }^{\ddagger}$
}

February 3, 2010

\begin{abstract}
Using Italian data this study estimates the option value model in order to quantify the effect of financial incentives on retirement choices. As far as we know, this is the first empirical study which estimates the conditional multiple-years (CMY) model put forward by Stock and Wise (1990). This implies that we have accounted for dynamic self-selection bias.

For the subsample of females the CMY model yields plausible estimates of the preference parameters such as the marginal utility of leisure. This last parameter is typically underestimated if one does not take into account the self-selection problem. From our results it becomes clear that dynamic self-selection results in a considerable downward-bias in the estimate of the marginal utility of leisure. We also performed a simulation study to gauge the effects of a dramatic pension reform. It turns out that the underestimation of the marginal utility of leisure translates into a sizable overprediction of the impact of the reform. For males we also obtain plausible estimates. The results for males should be interpreted with caution because we are not able to fully correct for dynamic self-selection bias.
\end{abstract}

Keywords: retirement, option value model, dynamic self-selection JEL codes: J26, H55, C33, C34, C35.

*The authors are grateful to Hugo Benitez-Silva, Christopher Flinn, Eric French, Adriaan Kalwij, John Rust and Daniël van Vuuren for their useful comments. They also appreciated comments made by the participants to the 7th workshop "Marie Curie Research Training Network - The Economics of Ageing", to the workshop for the presentation of Ph.D. DSE thesis and to the seminar at Central Planning Bureau. The research was partly supported by grant from MIUR. All opinions and errors are those of the authors alone.

${ }^{\dagger}$ CeRP - Collegio Carlo Alberto. Address for correspondence: Via Real Collegio, 30, 10024 Moncalieri (TO), Italy, E-mail: belloni@cerp.unito.it

${ }^{\ddagger}$ University of Groningen, Netspar and Tinbergen Institute, E-mail: r.j.m.alessie@rug.nl 


\section{Introduction}

Increasing the average retirement age from the labor force is in the political agenda of almost all developed countries. It is generally accepted as the most effective solution to the pay-as-you-go pension crises caused by aging, increased life expectancy and low growth. How to obtain this increase is a more debated issue. A shared policy acts on financial incentives, by either tightening the access to benefits or discouraging early retirement through e.g. the introduction of actuarially fair pension schemes. The effectiveness of these policies crucially depends on the importance of financial incentives on retirement choices.

The effects of financial incentives on retirement have been investigated in many studies which use reduced-form models (see e.g. Gruber and Wise 2004b). It is well known (Lucas 1976) that structural models are more suitable than reduced-form models to evaluate the impact of reforms. Between the structural retirement models focusing on financial incentives which have been developed in the literature, the "option value model" (Stock and Wise 1990) is one of the most known. In this model the worker is assumed to be forward looking. At each age she chooses whether to retire by comparing the expected utility associated with retiring with the maximum between the expected utilities associated with retiring at any future age. If the former is greater than the latter, then the worker retires; otherwise, she continues working. In this second case, retirement is re-evaluated once new information on wages and pension benefits becomes available. Transitions back to work are not modeled, since retirement is assumed to be an absorbing state.

In the option value (OV) model, utility is given to individuals by both consumption and leisure. Consumption is approximated by current income. Leisure is benefited only by retirees (i.e. part-time work is excluded). Unobserved determinants of retirement are accounted for in the stochastic component of the model. Since most of them - such as preference for leisure, or typically health conditions - can be persistent over time, the error term of the utility functions is modeled by Stock and Wise as an autoregressive process.

Dynamic programming (DP) (see e.g. Heyma 2004, Burkhauser, Butler, and Gumus 2004) is the best known alternative approach to the OV model in the retirement literature. OV and DP models share many key features. They however differ in the way uncertainty is treated: the OV model compares the 
expected utility of retiring now with the maximum value of expected future utilities, whereas DP models compare the expected value of the maximum of current versus future retirement options. Given the Jensen's inequality, the OV model undervalues future retirement options (Lumsdaine, Stock, and Wise 1995). However, various empirical applications show that OV and DP models give similar results (see Lumsdaine, Stock, and Wise 1995, Burkhauser, Butler, and Gumus 2003).

Stock and Wise (1990) estimate two versions of the OV model: the single-year (SY henceforth) model and the multiple-years (MY) model. The first one evaluates retirement probabilities in a single cross-section (the base year). The MY model is an improvement over the SY model because it considers retirement decisions over multiple years. In the MY model one can allow for a more flexible stochastic specification of the OV model than in the SY model, i.e. one can assess the extent of persistency of preference shocks 1

Stock and Wise (1990) impose an age selection on the data when they estimate the SY model. Consequently, their cross-section (base year) data also contains old employees, e.g. aged 60. Notice that such employees could have retired earlier. Consequently, work loving individuals might be over-represented in their estimation sample. In other words, the estimates of the SY model may be not consistent because of dynamic self-selection bias. In particular, by over-representing work-lovers, the SY model may underestimate the marginal utility of leisure. The estimates of the MY model presumably also suffer from dynamic self-selection bias because old workers are also in the base year of the longitudinal dataset.

Stock and Wise (1990) were well aware of the dynamic self-selection problem. Therefore they formulated the conditional multiple-years OV model (CMY). The CMY model evaluates the retirement probability in the base year (and in the following years) conditional upon retirement choices taken by the workers before the base year. In this model, the likelihood contribution of older workers - who presumably started to consider retirement well before the base year - is a joint high-dimensional probability. The state-of-the-art in numerical integration existing at the time the Stock and Wise's study was conducted did not allow for a reliable approximation of

\footnotetext{
${ }^{1}$ Stock and Wise (1990) assume that preference shocks are fully persistent when they estimate the SY model.
} 
high-dimensional integrals. This may explain why the authors have not estimated conditional probability models in their paper.

Subsequent estimates of the option value model followed the seminal work of Stock and Wise. Repeated observations for each individual were often available to the authors of these studies. Nevertheless, almost all studies estimated the SY version of the model 2 Most of them found unsatisfactory results. For instance, Harris (2001) and Hurd, Loughran, and Panis (2003) made use of the Health and Retirement Study to test the option value model on a population of workers covered by heterogeneous pension schemes. They found implausible estimates for some crucial coefficients, such as the marginal utility of leisure, and often a bad fit. Spataro (2000b) performed a similar exercise on Italian survey data, finding comparable difficulties ${ }^{3}$

This paper contributes to the existing literature in the sense that we estimate a CMY model thereby accounting for dynamic self-selection. In this exercise we use Italian administrative data. To our knowledge, no empirical applications of the conditional probability OV model exist in the literature. This may be partly due to the lack of sufficiently long datasets which are needed to correct for self-selection. Moreover, a little relevance has been given to the effects of self-selection bias on the OV parameter estimates. In order to highlight the effect of self-selection, we also estimate SY and MY models and we compare their estimated parameters with those of the CMY model.

Information on earnings, social security benefits and retirement choices are taken from the "Working History Italian Panel" (WHIP) dataset merged with an additional pension file which provides information on seniority. This data has been previously used only by Belloni and Alessie (2009). In comparison with previous data used to study retirement in Italy, it has two main advantages. First, it allows for a more complete tracking of transitions into the labor market, providing a more precise definition of the retirement status. Second, by reporting information on seniority, it permits an accurate reconstruction of workers' financial incentives. Belloni and Alessie (2009) provide empirical evidence that, without good information on

\footnotetext{
${ }^{2}$ As far as we know, only Danø, Ejrnaes, and Husted (2005) exploited the longitudinal dimension of the data and estimated the MY model.

${ }^{3}$ More satisfactory results were found by Lumsdaine, Stock, and Wise (1992) and Burkhauser, Butler, and Gumus (2003). They compared the predictive validity of the (SY version of the) OV model and some simple DP models.
} 
seniority, reduced-form models explaining the retiring probability by means of financial incentives give implausible results.

Unfortunately, the longitudinal dimension of our data (16 years) allows for a full correction of self-selection bias only for females. For this reason, our empirical analysis is mainly focused on females retirement. To facilitate the comparison with previous studies, which - with few exceptions - analyzed retirement behavior of males, we estimate the model also for males. For them, we allow for the value of leisure to depend on age.

The paper proceeds as follows. Section 2 gives an overview of the Italian institutional framework. Sections 3 and 4 describe the option value model, the data and sample selection. Section 5 summarizes the estimation results and presents a policy simulation. Section 6 concludes.

\section{Institutions}

Before the 1990s, the Italian social security system was characterized by a very generous defined benefit (DB henceforth) formula and by attractive early retirement options. Benefits greater than 80 percent of the last wage were frequently granted. No actuarial adjustments were applied to early exits, generating an high "implicit tax" on continuing to work (Brugiavini 1999). This generosity was one of the main causes of the striking decrease in the labor force participation rate of older workers in Italy in the last decades of the twentieth century. For example, the labor force participation rate of males aged 60-64 decreased from 60 percent in 1960 to 35 percent in 1990 (Gruber and Wise 1999). Pension expenditure grew dramatically in these decades: from 7.4 percent of GDP in 1970 to 14.9 percent in 1992 (Brugiavini and Galasso 2004).

To reestablish the social security budget equilibrium, an impressive series of reforms were introduced by the Italian Government during the 1990s. The most noticeable ones are those of 1992 and 1995. The reform of 1992 mainly modified the pension indexation from wage-based to price-based. It also tightened the minimum requirements for the old-age pension and lengthened the period of the working career to be accounted for in the benefits computation. Although these changes drastically reduced total outstanding liabilities, they were considered insufficient to guarantee financial sustainability, especially in the long run. 
In 1995 a further reform was thus introduced. It affected in particular pension rights of younger workers, i.e. those who started working after 1995 and retiring after 2030. For these workers, the generous DB pension formula was replaced by a defined contribution (DC) one, which grants a return equal to the GDP growth and applies actuarial reductions to early retirement. According to Fornero and Castellino (2001), the implicit taxation on continuing to work characterizing the DB formula will almost disappear in the new system. A pro-rata mechanism, where old and new rules are applied in proportion to the seniority accrued before and after 1995, was applied to middle-aged workers. Older workers were affected by the 1995 reform through an increase in minimum requirements to access early retirement. Nevertheless, their benefits were left untouched by the reform, i.e. they are computed according to the old DB formula.

The continuous changes in the pension law of the 1990s - often fully applied only after a long transitional phase - generated a complicated legal framework. Moreover, different rules have applied to different workers, although a partial harmonization has been obtained. In this paper we analyze the retirement behavior of employees enrolled in the Fondo Pensioni Lavoratori Dipendenti (FPLD) fund 4 The FPLD is the main pension scheme for private sector employees. In 2008, it paid around 10 millions of pensions (INPS 2009). It is managed by the Istituto Nazionale della Previdenza Sociale (INPS), the most important social security institution in Italy.

For private sector employees the main exit routes to retirement have ever been the old-age and the seniority pensions. Prior to the 1992 pension reform, a female (male) worker could claim an old-age pension starting from age 55 (60), conditional on having accrued 15 years of seniority. Starting from 1993, the minimum eligibility age for the old age pension was gradually increased from 55 (60) to 60 (65) for females (males). Similarly, the minimum seniority rule was also tightened gradually by 5 years (from 15 years to 20 years). The transition to the new requirements was then made shorter by a law in 1994. Until 1995, the seniority pension could be claimed at any age, once 35 years of contributions had been accrued 5 Consequently, employees

\footnotetext{
${ }^{4} \mathrm{~A}$ comprehensive description of the social security reforms in Italy is given in Brugiavini and Galasso (2004).

${ }^{5}$ According to our data, older female workers, whose careers have been generally shorter and more interrupted than males', typically take up an old age pension. Older males, however, typically take up a seniority pension.
} 
who started their working career rather early, could easily retire at age 50 or so 6 The 1995 reform severely restricted access to a seniority pension in three ways. First, it gradually increased the minimum years of contribution from 35 to 40 . Second, it introduced an alternative eligibility rule, combining a minimum age with a minimum seniority 7 Third, the reform introduced the 'exit window' mechanism. According to it, eligible workers who claim benefits, must wait for 3-12 additional months 8 Furthermore, during the 1990s, the access to seniority pensions was periodically blocked (e.g. in 1993), in order to avoid sizable exits as an impulsive reaction of workers to the fear of further reforms.

The DB benefit formula is the same for old age and seniority pensions. It is computed as the product of three factors: pensionable earnings (PE), seniority and return rate. PE are the average earnings of the last years of work. The number of years to be accounted for in its computation was 5 before the reforms, gradually raised up to 10 by the reform of 1992. Given the generally upward-sloping lifetime wage profile, this legal change mostly resulted in lower pensions. It affected more white collar than blue collar workers, since the wage profile of the former is typically steeper than that of the latter. Up to 40 years of seniority can be accrued: working longer is thus discouraged (unless it increases $\mathrm{PE}$ ). The return rate is a decreasing function of PE. However, a constant 2 percent return applies to most deciles of the earnings distribution. If the application of the above described formula results in a benefit which is below a given threshold (so called pensione minima), the difference is subsidized if an earnings test is passed.

Payroll taxes for employees are particularly high. They grew from 25.21 to 32.7 percent of the wage during the analyzed period. Two thirds are paid by the employer and one third by the employee. In principle, retirement is not compulsory to claim pension benefits. However, there is a strong financial incentive to retire at claiming: if a worker (particularly an employee) continues working while benefiting a pension, his total income is heavily taxed 9 Our data confirms that very few pension beneficiaries work.

\footnotetext{
${ }^{6}$ Notice that, in addition to standard years of work, the valid contributory history of each individual also includes 'notional' contributions made during temporary out-of-work periods (e.g. unemployment, maternity leaves and military service).

${ }^{7} \mathrm{~A}$ reform in 1997 made then the transition to these rules quicker for white collars.

${ }^{8}$ Table 1 in Belloni and Alessie (2009) summarizes the reforms described above.

${ }^{9}$ The legislation on this point is extremely complicated and has been in continuous evolution in the last decades. Tax rules differ depending on the type of pension, type of
} 
In addition to old-age and seniority pensions, other social security programs financing retirement in Italy are the disability pension and some type of unemployment benefits targeted to older workers (long-run mobility scheme, so-called mobilità lunga). Until the early 1980s, the disability pension was attractive, easily granted and often used as an early retirement scheme. In 1984, a reform made its use less discretionary and subject to periodical medical checks. As a consequence of the reform, in few years its use as early exit route was substantially reduced (Brugiavini 1999). Mobility programs temporarily subsidize workers who are collectively fired by firms during a recessional phase, favoring re-employment in the labor market. The long-run mobility scheme has another aim, since it allows older workers who have few chances to be re-employed to retire prematurely. Therefore, it has been used as a 'bridge' to the old-age pension 10

\section{The option value model}

\subsection{Analytical description}

Suppose that the individual is forward-looking. Her lifetime utility at time (year) $t$ is given by $\sum_{s=t}^{\Omega} \beta^{s-t} u\left(c_{s}, l_{s}\right)$ where $u($.$) is the instantaneous util-$ ity, $c_{s}$ is consumption at time $s, l_{s}$ is leisure, a dummy variable indicating whether or not an individual works. Finally, $\beta$ denotes the discount factor and $\Omega$ the year in which the individual reaches the maximum attainable age. In the OV model one abstracts from saving, so that consumption is equal to current income. Let $Y_{s}$ be the earnings from work in year $s$ and $B_{s}(r)$ the pension and social security benefits received in year $s$ if retirement is in year $r(s \geq r)$. Then $u\left(Y_{s}, 0\right)=U_{W}\left(Y_{s}\right)$ in case the individual works and $u\left(B_{s}(r), 1\right)=U_{R}\left(B_{s}(r)\right)$ in case she is retired.

The individual chooses in year $t$ the retirement year $r$ in such a way that the expected value of the following value function is maximized

$$
V_{t}(r)=\sum_{s=t}^{r-1} \beta^{s-t} U_{W}\left(Y_{s}\right)+\sum_{s=r}^{\Omega} \beta^{s-t} U_{R}\left(B_{s}(r)\right)
$$

worker, and year of application.

${ }^{10}$ Eligibility for the long-run mobility scheme requires a minimum age, seniority and living in areas characterized by high unemployment. Long-run mobility schemes were introduced in the early 1990s, and partly replaced the previously existing pre-pensionamento. 
The worker solves this problem by comparing the expected value of retiring in year $t$ with the greatest between the expected values of retiring in any of the future years $r$ Define the expected gain from postponing retirement as

$$
G_{t}\left(r^{*}\right)=E_{t} V_{t}\left(r^{*}\right)-E_{t} V_{t}(t)
$$

where $r^{*}=\operatorname{argmax} E_{t} V_{t}(r)$ for $r \in\left\{t+1, \ldots, t_{\max }\right\}$ and $t_{\max }$ is the year in which the worker reaches her mandatory retirement age. The worker then retires in year $t$ if $G_{t}\left(r^{*}\right) \leq 0$, otherwise she postpones retirement.

The instantaneous utilities have the constant relative risk aversion form

$$
\begin{aligned}
& U_{W}\left(Y_{s}\right)=Y_{s}^{\gamma}+v_{s} \\
& U_{R}\left(B_{s}\right)=\left(\kappa B_{s}(r)\right)^{\gamma}+\omega_{s}
\end{aligned}
$$

where the parameter $\kappa$ represents the relative value of income in the status of retiree to income in the status of worker. We expect that individuals dislike work, i.e. $u\left(c_{s}, 1\right)>u\left(c_{s}, 0\right)$ or $\kappa>1$. The parameter $\gamma$ represents the curvature of the utility function with respect to future income; it can also be interpreted as a measure of risk aversion. This parameter is expected to be less than one if workers are risk-averse and greater than one if they are risk-lovers. $v_{s}$ and $\omega_{s}$ are time-and-individual specific random variables. $v_{s}$ and $\omega_{s}$ are assumed to be independent of earnings. They capture unobserved determinants of retirement, such as preference for leisure, private wealth and health conditions. Since these determinants are typically persistent over time, the random variables are modeled as a first order Markov process of the typ $\AA^{12}$

$$
\begin{array}{cl}
v_{s}=\rho v_{s-1}+\phi_{s} & E_{s-1}\left(\phi_{s}\right)=0 \\
\omega_{s}=\rho \omega_{s-1}+\psi_{s} & E_{s-1}\left(\psi_{s}\right)=0
\end{array}
$$

Inserting equations (3,4) into equation (2) results in

$$
\begin{aligned}
G_{t}(r) & =E_{t} \sum_{s=t}^{r-1} \beta^{s-t}\left[Y_{s}^{\gamma}+v_{s}\right]+E_{t} \sum_{s=r}^{\Omega} \beta^{s-t}\left[\left(\kappa B_{s}(r)\right)^{\gamma}+\omega_{s}\right] \\
& -E_{t} \sum_{s=t}^{\Omega} \beta^{s-t}\left[\left(\kappa B_{s}(t)\right)^{\gamma}+\omega_{s}\right]
\end{aligned}
$$

\footnotetext{
${ }^{11}$ The model allows for three types of uncertainty: future income, lifetime and future preferences shocks (future values of $\phi_{s}$ and $\psi_{s}$ in equations 5 and 6 ).

${ }^{12}$ Like Stock and Wise (1990) we assume $\rho$ to be the same in equations $\sqrt[5]{5}$ and $(6)$.
} 
Splitting it into a deterministic and a stochastic component, and accounting for survival probabilities yields

$$
\begin{aligned}
g_{t}(r)= & \sum_{s=t}^{r-1} \beta^{s-t} \pi(s \mid t) E_{t}\left[Y_{s}^{\gamma}\right]+\sum_{s=r}^{\Omega} \beta^{s-t} \pi(s \mid t) E_{t}\left[\left(\kappa B_{s}(r)\right)^{\gamma}\right] \\
& -\sum_{s=t}^{\Omega} \beta^{s-t} \pi(s \mid t) E_{t}\left[\left(\kappa B_{s}(t)\right)^{\gamma}\right] \\
\varphi_{t}(r)= & \sum_{s=t}^{r-1} \beta^{s-t} \pi(s \mid t) E_{t}\left[v_{s}-\omega_{s}\right] \\
G_{t}(r)= & g_{t}(r)+\varphi_{t}(r)
\end{aligned}
$$

where $\pi(s \mid t)$ are conditional survival probabilities 13 Given the Markov assumption, $\varphi_{t}(r)$ simplifies to

$$
\varphi_{t}(r)=\sum_{s=t}^{r-1} \beta^{s-t} \pi(s \mid t) \rho^{s-t}\left[v_{t}-\omega_{t}\right]
$$

Rewriting $K_{t}(r)=\sum_{s=t}^{r-1}(\beta \rho)^{s-t} \pi(s \mid t)$ and $\xi_{t}=v_{t}-\omega_{t}$, then

$$
G_{t}(r)=g_{t}(r)+K_{t}(r) \xi_{t}
$$

Notice that the error term is heteroskedastic: the farther the retirement age, the higher $K_{t}(r)$. This model characteristic captures the greater uncertainty associated with future retirement.

\subsection{Retirement probabilities}

\subsubsection{Single-year (SY) model}

Suppose that we observe retirement choices in a single year (year $t$ ). The probability for a worker to retire in $t$ is given by

$$
\operatorname{Pr}[R=t]=\operatorname{Pr}\left[G_{t}\left(r^{*}\right) \leq 0\right]=\operatorname{Pr}\left[g_{t}\left(r^{*}\right) / K_{t}\left(r^{*}\right) \leq-\xi_{t}\right]
$$

and $\operatorname{Pr}[R>t]=1-\operatorname{Pr}[R=t]$. Assuming that $\xi_{t}$ is normally distributed with variance $\sigma_{\xi}^{2}$, the sample likelihood becomes

$$
\mathscr{L}=\prod_{i} \Phi\left[-\frac{d_{i t} g_{i t}\left(r_{i t}^{*}\right)}{K_{i t}\left(r_{i t}^{*}\right) \sigma_{\xi}}\right]
$$

\footnotetext{
${ }^{13}$ We implicitly assume that whether an individual is alive in future years is stochastically independent of her stream of future earnings and of preference shocks.
} 
where $d_{i t}=2 y_{i t}-1$, and $y_{i t}=1$ if worker $i$ retires in year $t$ while $y_{i t}=0$ otherwise. $\Phi$ is the standard normal c.d.f. The likelihood contains five unknown parameters: $\kappa, \beta, \gamma, \sigma_{\xi}$ and $\rho$. Standard maximum likelihood techniques can be applied to estimate them.

The estimation of the SY model only requires the availability of a single cross-section. Parameters are identified through between-individuals variation. However, in practice, a cross-section dataset does not contain enough information to estimate $\rho$ with great precision. Therefore we follow Stock and Wise (1990) who assume that $\xi_{t}$ follows a random walk process $(\rho=1)$. Another relevant shortcoming of the SY model concerns the sample selection. For instance, a cross-section dataset would typically include employees aged 60 who had the opportunity to retire before that age. These individuals might have chosen to not retire because they love working. The likelihood (14) does not take into account this type of endogenous sample selection. Consequently, maximizing the likelihood (14) would probably yield inconsistent estimates. In particular, the value of leisure - the $\kappa$ parameter - may be underestimated, since individuals with a stronger preference for leisure may have exited the data before year $t$.

\subsubsection{Multiple-years (MY) model}

Suppose that we observe retirement choices for multiple years, say from $t$ to $T$. Consider the case of a worker who retire in year $\tau$, where $\tau \in\{t, \ldots, T\}$. Then, it must have been not optimal for her to retire up to year $\tau-1$, i.e. that $G_{t}\left(r_{t}^{*}\right)>0, \ldots, G_{\tau-1}\left(r_{\tau-1}^{*}\right)>0$. In year $\tau$ retirement is optimal, and therefore $G_{\tau}\left(r_{\tau}^{*}\right) \leq 0$. Specifying $G_{t}(r)$ as in equation (12), the (joint) probability for a worker to retire in year $\tau$ is given by

$$
\begin{aligned}
\operatorname{Pr}[R=\tau]= & \operatorname{Pr}\left[g_{t}\left(r_{t}^{*}\right) / K_{t}\left(r_{t}^{*}\right)>-\xi_{t}, \ldots,\right. \\
& g_{\tau-1}\left(r_{\tau-1}^{*}\right) / K_{\tau-1}\left(r_{\tau-1}^{*}\right)>-\xi_{\tau-1}, \\
& \left.g_{\tau}\left(r_{\tau}^{*}\right) / K_{\tau}\left(r_{\tau}^{*}\right) \leq-\xi_{\tau}\right]
\end{aligned}
$$

Due to the reasons explained in the data section, we do not observe everyone retiring in the sample period. Therefore, the probability that the individual 
does not retire by year $T$ is given by

$$
\begin{aligned}
\operatorname{Pr}[R>T]= & \operatorname{Pr}\left[g_{t}\left(r_{t}^{*}\right) / K_{t}\left(r_{t}^{*}\right)>-\xi_{t}, \ldots .,\right. \\
& g_{T-1}\left(r_{T-1}^{*}\right) / K_{T-1}\left(r_{T-1}^{*}\right)>-\xi_{T-1}, \\
& \left.g_{T}\left(r_{T}^{*}\right) / K_{T}\left(r_{T}^{*}\right)>-\xi_{T}\right]
\end{aligned}
$$

The following Markov process is assumed for $\$ 14$

$$
\xi_{s}=\rho \xi_{s-1}+\nu_{s} \quad \nu_{s} \text { i.i.d. } \quad N\left(0, \sigma_{\nu}^{2}\right)
$$

for $s=t+1, \ldots, \tau$, while $\xi_{t}$ is i.i.d. $N\left(0, \sigma_{\xi}^{2}\right)$. It follows that the vector $\xi_{t}, \ldots, \xi_{\tau}$ is multivariate normal distributed with mean zero, $\operatorname{var}\left(\xi_{s}\right)=$ $\rho^{2(s-t)} \sigma_{\xi}^{2}+\sum_{i=0}^{s-t-1} \rho^{2 i} \sigma_{\nu}^{2}$ and $\operatorname{cov}\left(\xi_{s}, \xi_{t}\right)=\rho^{s-t} \operatorname{var}\left(\xi_{t}\right)$.

The sample likelihood is therefore

$$
\mathscr{L}=\prod_{i}\left[\int \ldots \int_{-\infty}^{A_{i}} f\left(\xi_{t}, \ldots, \xi_{\tau}\right) \mathrm{d} \xi_{t} \ldots \mathrm{d} \xi_{\tau}\right]
$$

where

$$
\begin{aligned}
A_{i}= & \left\{g_{i t}\left(r_{i t}^{*}\right) /\left[K_{i t}\left(r_{i t}^{*}\right) \sigma_{\xi}\right], \ldots,\right. \\
& g_{i \tau-1}\left(r_{i \tau-1}^{*}\right) /\left[K_{i \tau-1}\left(r_{i \tau-1}^{*}\right) \sqrt{\operatorname{var}\left(\xi_{\tau-1}\right)}\right], \\
& \left.-\left[d_{i \tau} g_{i \tau}\left(r_{i \tau}^{*}\right)\right] /\left[K_{i \tau}\left(r_{i \tau}^{*}\right) \sqrt{\operatorname{var}\left(\xi_{\tau}\right)}\right]\right\}
\end{aligned}
$$

and $d_{i \tau}=1$ if worker $i$ retires in $\tau \in\{t, \ldots, T\}$ or 0 otherwise, and $f$ is the $(\tau-t+1)$-variate standard normal density. The MY model is thus a kind of multivariate probit model with dependent errors.

Six parameters have to be estimated: $\kappa, \beta, \gamma, \sigma_{\xi}, \sigma_{\nu}$ and $\rho$. We apply simulated maximum likelihood methods to estimate them. Given its desirable properties (Hajivassiliou, McFadden, and Ruud 1996, Hajivassiliou 2000), we have used the GHK simulator to approximate the multi-dimensional integral which is present in the likelihood (18).

The longitudinal dimension of the dataset allows to precisely estimate the correlation coefficient $\rho$. Time variability can also be helpful in the

\footnotetext{
${ }^{14}$ Instead of the AR(1) process, we also experimented with the following specification for $\xi$ put forward by Dan $\varnothing$, Ejrnaes, and Husted (2005): $\xi_{s}=\mu+\epsilon_{s}$ where $\mu \sim N I D\left(0, \sigma_{\mu}^{2}\right)$ and $\epsilon_{s} \sim N I D\left(0, \sigma_{\epsilon}^{2}\right)$. The attractive feature of this specification is that by conditioning on the individual effect $\mu$, the likelihood function is reduced to a one-dimensional integral, i.e. the likelihood is much easier to compute. However, it turned out that by using the specification of Danø, Ejrnaes, and Husted (2005) the fit of the model is much worse.
} 
identification of the other model parameters. This is especially true if, in the period under analysis, some policy changes affected workers' financial incentives. This is the case in our sample (see section 2).

Like Stock and Wise (1990), we impose an age selection on the data. Consequently, the first wave of our longitudinal estimation sample contains old employees, e.g. aged 65. Notice that such employees could have retired earlier. Consequently, work-loving individuals might be over-represented in our estimation sample. Therefore, as the SY model, the MY model may provide inconsistent estimates - especially for the $\kappa$ parameter - due to sample selection bias.

\subsubsection{Conditional multiple-years (CMY) model}

Stock and Wise (1990) have also proposed a method to correct for the sample selection bias problem described in the previous subsection. Assume that workers start considering retirement in year $t_{0} \leq t$. According to the conditional multiple-years (CMY) model, the probability for a worker to retire in year $\tau$, for $\tau \in\{t, \ldots, T\}$, is

$$
\begin{aligned}
\operatorname{Pr}[R=\tau \mid R>t-1]= & \operatorname{Pr}[R=\tau] / \operatorname{Pr}[R>t-1]= \\
& \operatorname{Pr}\left[g_{t_{0}}\left(r_{t_{0}}^{*}\right) / K_{t_{0}}\left(r_{t_{0}}^{*}\right)>-\xi_{t_{0}}, \ldots,\right. \\
& g_{\tau-1}\left(r_{\tau-1}^{*}\right) / K_{\tau-1}\left(r_{\tau-1}^{*}\right)>-\xi_{\tau-1}, \\
& \left.g_{\tau}\left(r_{\tau}^{*}\right) / K_{\tau}\left(r_{\tau}^{*}\right) \leq-\xi_{\tau}\right] / \\
& \operatorname{Pr}\left[g_{t_{0}}\left(r_{t_{0}}^{*}\right) / K_{t_{0}}\left(r_{t_{0}}^{*}\right)>-\xi_{t_{0}}, \ldots,\right. \\
& \left.g_{t-1}\left(r_{t-1}^{*}\right) / K_{t-1}\left(r_{t-1}^{*}\right)>-\xi_{t-1}\right]
\end{aligned}
$$

and

$$
\begin{aligned}
\operatorname{Pr}[R>T \mid R>t-1]= & \operatorname{Pr}[R>T] / \operatorname{Pr}[R>t-1]= \\
& \operatorname{Pr}\left[g_{t_{0}}\left(r_{t_{0}}^{*}\right) / K_{t_{0}}\left(r_{t_{0}}^{*}\right)>-\xi_{t_{0}}, \ldots,\right. \\
& \left.g_{T}\left(r_{T}^{*}\right) / K_{T}\left(r_{T}^{*}\right)>-\xi_{T}\right] / \\
& \operatorname{Pr}\left[g_{t_{0}}\left(r_{t_{0}}^{*}\right) / K_{t_{0}}\left(r_{t_{0}}^{*}\right)>-\xi_{t_{0}}, \ldots,\right. \\
& \left.g_{t-1}\left(r_{t-1}^{*}\right) / K_{t-1}\left(r_{t-1}^{*}\right)>-\xi_{t-1}\right]
\end{aligned}
$$

The sample likelihood is

$$
\mathscr{L}=\prod_{i}\left[\frac{\int \cdots \int_{-\infty}^{B_{i}} f\left(\xi_{t_{0}}, \ldots, \xi_{\tau}\right) \mathrm{d} \xi_{t_{0}} \ldots \mathrm{d} \xi_{\tau}}{\int \cdots \int_{-\infty}^{C_{i}} f\left(\xi_{t_{0}}, \ldots, \xi_{t-1}\right) \mathrm{d} \xi_{t_{0}} \ldots \mathrm{d} \xi_{t-1}}\right]
$$


where

$$
\begin{aligned}
B_{i}= & \left\{g_{i t_{0}}\left(r_{i t_{0}}^{*}\right) /\left[K_{i t_{0}}\left(r_{i t_{0}}^{*}\right) \sigma_{\xi}\right], \ldots,\right. \\
& g_{i \tau-1}\left(r_{i \tau-1}^{*}\right) /\left[K_{i \tau-1}\left(r_{i \tau-1}^{*}\right) \sqrt{\operatorname{var}\left(\xi_{\tau-1}\right)}\right], \\
& \left.-\left[d_{i \tau} g_{i \tau}\left(r_{i \tau}^{*}\right)\right] /\left[K_{i \tau}\left(r_{i \tau}^{*}\right) \sqrt{\operatorname{var}\left(\xi_{\tau}\right)}\right]\right\} \\
C_{i}= & \left\{g_{i t_{0}}\left(r_{i t_{0}}^{*}\right) /\left[K_{i t_{0}}\left(r_{i t_{0}}^{*}\right) \sigma_{\xi}\right], \ldots,\right. \\
& \left.g_{i t-1}\left(r_{i t-1}^{*}\right) /\left[K_{i t-1}\left(r_{i t-1}^{*}\right) \sqrt{\operatorname{var}\left(\xi_{t-1}\right)}\right]\right\}
\end{aligned}
$$

and $f$ is the $\left(\tau-t_{0}+1\right)$-variate standard normal density.

The unknown parameters and the optimization methods used to estimate the CMY model are the same of the MY model. In addition, one needs a) an assumption on the first age at which workers start to evaluate retirement, and b) a sufficiently long dataset allowing to observe retirement choices since that age onwards, for each worker in the sample in year $t$. For instance, if the first age at which workers start to evaluate retirement is set to 50, a worker aged 65 in $t$ needs to be observed backward starting from year $t_{0}=t-15$. In principle, retirement may even occur in the first year of employment. In practice, one may assume that the first possible retirement age is the first age at which exits to retirement are observed in the data, e.g. age 50.

\subsection{Computation of $g_{t}(r)$}

In order to compute $g_{t}(r)$ (see equation 8) we need to evaluate, for each worker in the sample, the following expectations: $E_{t}\left[Y_{s}^{\gamma}\right]$ and $E_{t}\left[\left(\kappa B_{s}(r)\right)^{\gamma}\right]$ for $s>t$. Consider the wage model in Belloni and Alessie (2009). This model can be rewritten as follow 15

$$
\begin{aligned}
\ln \left(Y_{i t}\right) & =\theta_{t-y o b_{i}}+\lambda_{t}+c_{i}+u_{i t} \\
u_{i t} & =\varrho u_{i t-1}+\epsilon_{i t}, \quad \epsilon_{i t} \sim N I D\left(0, \sigma_{\epsilon}^{2}\right)
\end{aligned}
$$

where $Y_{i t}$ denotes real annualized wages net of social security contributions paid by the employer, $y o b_{i}$ denotes year of birth and $c_{i}$ is a random effect capturing individual unobserved heterogeneity. The $\theta$-parameters capture age effects, and the $\lambda$-parameters time effects. In equation (22), the $\theta$ and $\lambda$-parameters cannot be identified separately due to the perfect collinearity between the variables age (i.e. $t-y o b_{i}$ ), calendar year and year of birth

\footnotetext{
${ }^{15}$ Cf. equations (4) and (5) in Belloni and Alessie (2009).
} 
(subsumed in $c_{i}$ ). To address this problem we follow the suggestion of Deaton and Paxson (1994), and impose the following two restrictions on the $\lambda$ parameters: 1) they add up to zero; 2) they are orthogonal to a time trend. The wage model (22)-(23) is estimated separately by gender and occupation (blue versus white collar workers) using WHIP data. ${ }^{16}$

Equations (22) and (23) imply that for $s>t$

$$
\begin{aligned}
E_{t}\left(Y_{i s}^{\gamma}\right) & =Y_{i t}^{\gamma} E_{t} \exp \left(\gamma\left(\ln Y_{i s}-\ln Y_{i t}\right)\right) \\
& =Y_{i t}^{\gamma} \exp \left(\gamma\left(\left(\theta_{s-y o b_{i}}-\theta_{t-y o b_{i}}\right)+\left(\varrho^{s-t}-1\right) u_{i t}\right) E_{t}\left(\exp \left(z_{i t}^{s}\right)\right)\right.
\end{aligned}
$$

where $z_{i t}^{s}=\gamma \sum_{j=t+1}^{s} \varrho^{s-j} \epsilon_{i j}$. Since the income shocks $\epsilon_{i j}$ are assumed to be normally distributed (cf. equation 23 ), it holds that $z_{i t}^{s} \sim N\left(0, \sigma_{t s}^{2}\right)$ where

$$
\sigma_{t s}^{2}=\sigma_{\epsilon}^{2} \gamma^{2} \sum_{j=t+1}^{s} \varrho^{2(s-j)}=\sigma_{\epsilon}^{2} \gamma^{2} \frac{1-\left(\varrho^{2}\right)^{s-t}}{1-\varrho^{2}}
$$

Consequently,

$$
E_{t}\left(Y_{i s}^{\gamma}\right)=Y_{i t}^{\gamma} \exp \left(\gamma\left(\left(\theta_{s-y o b_{i}}-\theta_{t-y o b_{i}}\right)+\left(\varrho^{s-t}-1\right) u_{i t}\right)\right) \exp \left(\sigma_{t s}^{2} / 2\right)
$$

Following Stock and Wise (1990) ${ }^{17}$ we approximate $E_{t}\left[\left(\kappa B_{s}(r)\right)^{\gamma}\right]$ with $\left(\kappa \bar{B}_{s}(r)\right)^{\gamma} . \bar{B}$ is the social security benefit computed on the basis of observed wages up to year $t$ and of forecasted wages from year $t+1$ to year $r-1$. Forecasts are based on the wage model $222-23$.

We only consider pension rules for old-age and seniority pensions in the FPLD scheme ${ }^{18}$ We assume that workers know current pension rules and hold static expectations, i.e. that they make their retirement plans assuming that the current rules will not be changed by future reforms. This is a rather standard assumption in the retirement literature (see e.g. Gruber and Wise (2004b) and Brugiavini and Peracchi (2004) for Italy). We realize that such assumption may be strong in the period of the reforms. Nevertheless, properly accounting for alternative expectation formation schemes would

\footnotetext{
${ }^{16}$ The estimation results are shown in Belloni and Alessie (2009). We also experimented alternative assumptions on the wage process, such as an autoregressive model and a model with constant expected wages. OV parameter estimates turned out to be robust to the different wage profiles.

${ }^{17}$ See footnote 12 in Stock and Wise (1990).

${ }^{18}$ See Belloni and Alessie (2009) appendix A.1. for a formal description of the DB formulas.
} 
have required subjective data on expected future pension rights (see e.g. Bottazzi, Jappelli, and Padula 2006, Chan and Stevens 2004).

Survival probabilities in $g_{t}(r)$ are evaluated allowing for variation by age, gender, cohort and region. The Italian Institute of Statistics publishes a long time series of life tables by age, gender and region (ISTAT 2008). From this data, we disentangle age from year of birth effects on mortality rates. As in Brugiavini and Peracchi (2003) and Belloni and Alessie (2009), we apply a minimum- $\chi^{2}$ method for the log-odds of mortality, using age and cohort as explanatory variables. The model is estimated separately by gender and region, for a total of 36 estimated models. Fitted values from these models are then used to predict survival probabilities.

\section{Data and sample selection}

\subsection{The WHIP data}

In this study, we use the WHIP data linked with an additional INPS pension file. WHIP is a random sample of the private sector non-agricultural workforce. It is drawn from an administrative archive managed by INPS. Workers are followed as far as they pay social security contributions to INPS or receive social security (e.g. unemployment or pension) benefits. They leave the archive when they stop contributing (e.g. because they leave the labor force, or start working in the public sector), or when they die. Therefore, the panel is unbalanced.

WHIP comprises a principal file - the 'O1M data' file - and other complementary files. The O1M data reports main employment spells characteristics such as wages, occupation, weeks worked and contract type. It spans 16 years: 1985-2001. The complementary files focus on spells of self-employment (artisans and traders), unemployment and mobility. They mainly show related earnings (or benefits). Information on pension benefits is obtained from an additional INPS pension file 19 This additional file shows the amount, the date of first payment, and the accrued seniority at

\footnotetext{
${ }^{19}$ Seniority cannot be observed for every worker in the O1M data, but only for those who received at least once pension benefits in the years 1985-2006. As a consequence, we cannot recover seniority for some group of workers, e.g. 1) young workers who retire after 2006; and 2) old workers who worked partly in the private sector - but not enough to become eligible for INPS benefits - and partly in the public (or agricultural) sector.
} 
retirement of all the pensions paid by INPS during the period 1985-2006.

This data has been previously used by Belloni and Alessie (2009). Early studies on retirement in Italy - including the OV estimate in Spataro (2000a) - have used the Bank of Italy's 'Survey of Household Income and Wealth' (SHIW) 20 Our data has several advantages with respect to survey data. A first one is that the key variables - wages and seniority - are measured with much less error. Another relevant one is that there is less attrition. Moreover, our data has a much bigger sample size, especially if compared with the panel component of the SHIW.

More recent studies on retirement in Italy have instead used the O1M data (see, e.g. Brugiavini and Peracchi 2004). In comparison with the O1M data, our data has two main advantages. The most important one is that it reports seniority. Belloni and Alessie (2009) provide empirical evidence that, without good information on seniority, reduced-form models explaining the retiring probability by means of financial incentives give implausible results. Obviously, information on seniority is also extremely relevant in this study. Second, our data better tracks transitions into the labor market. Previous studies assumed that workers were retired when they permanently left the O1M data. This assumption may be strong if employees transit to retirement non-smoothly, e.g. passing though periods of self-employment. Thanks to the complementary files, we can relax this assumption.

The main weakness of WHIP is that transitions from and to the public sector cannot be observed. In our study this is however not important, since we focus on workers aged 50 and older. Transitions between private and public sector are rare for these workers. Another weakness of our data is that few individual characteristics (gender, date and region of birth) can be observed. Finally, family status and households' characteristics are not available.

\subsection{Sample selection}

The sample selection is illustrated in figures 1 and 2 for females and males respectively. We select females aged 50 to 60 born between 1935 and 1945 . Empirical evidence shows that only a negligible number of female employees retire before age 50 and after age 60. In the SY model (see equation 14) we look at their retirement choices in 1995. Notice that by choosing this

\footnotetext{
${ }^{20}$ See also Colombino, Hermaes, Jia, and Strom (2002) and Colombino (2001).
} 
base year, we know seniority for everyone in the sample ${ }^{21}$ This allows to compute pension rights in the correct way (see section 2). In the MY model (see equation 18) we follow those females until retirement or up to a maximum of age 60. The relevant sample period for this 'MY sample' is 1995-2001. In the CMY model for the individuals who are in the sample in 1995 - to correct for sample selection bias, see equation (21) - we also use the information available in the period 1985-1994 as far as the worker is at least aged 5022

A preliminary data analysis suggests that males do not retire before age 50. Contrary to females, some males keep on working after age 60. However, almost all of them retire before age 66 . Therefore, we consider retirement choices between 50 and 65 . Since 2006 is the last year for which seniority is available, the youngest cohort which we can consider in the sample is 1941 (i.e. 2006-65). It also implies that the most appropriate choice for the base year is 1991 (i.e. 2006-(65-50)). In other words, for the estimation of the SY model, we select males born between 1926 and 1941 who are not retired at the beginning of 1991. In the MY model, we follow those individuals up to retirement or up to a maximum of age 65 . The relevant sample period for this 'MY sample' is 1991-2001. In the CMY model for the individuals who are in the sample in 1991 we also use the information available in the period 1985-1991 as far as the worker is at least aged 50. The correction for self-selection is incomplete for males, since workers born in 1934 or earlier can be only observed after age 50. For instance, the 1926 generation can be followed starting from age 59 onward (i.e. 1985-1926).

As already said, in this study we focus on retirement choices of private sector employees enrolled in the FPLD fund. An employee is considered retired if he/she leaves permanently the O1M archive and does not work later on as a self-employed (either as an artisan or a trader). Given that we

\footnotetext{
${ }^{21}$ Suppose that we had chosen 2000 as the base year. Selected cohorts would have been 1940-1950. Especially for the 1950 cohort, seniority would have not been observed for everyone since some individuals have not been retired before 2006 (the last year covered by the pension file). In the sample preparation, we should have deleted those individuals for which seniority is not known. Therefore this choice of the base year would have resulted in selecting only individuals with taste for leisure.

${ }^{22}$ Notice that by choosing as base year one of the years between 1985 and 1994 instead of 1995 would have resulted in a partial correction for self-selection bias in the CMY model. By choosing as base year one of the years between 1997 and 2001 would have resulted in the self-selection problem described in footnote 21.
} 
Figure 1: Sample selection: females

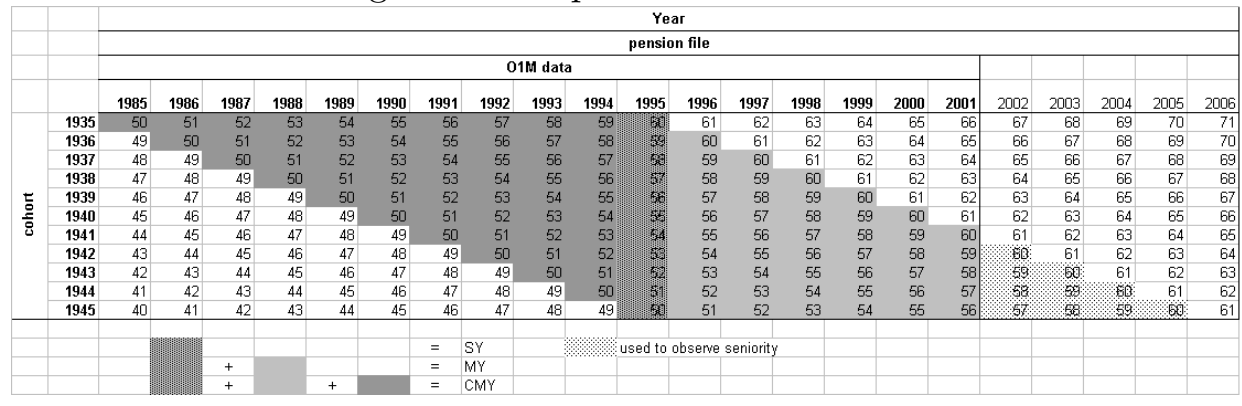

Figure 2: Sample selection: males

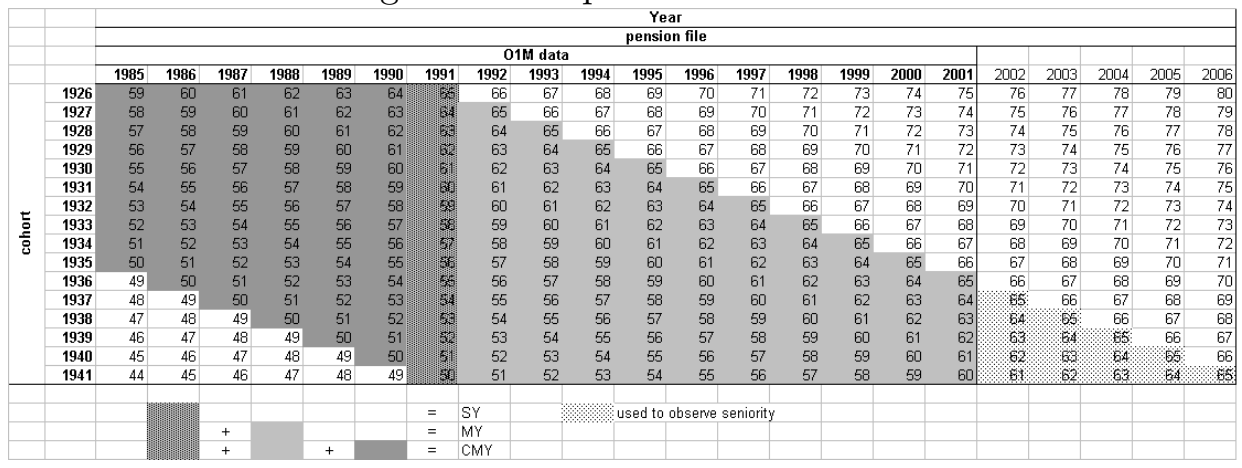

evaluate voluntary retirement choices, we do not consider transitions out of the labor force due to disability and mobility subsidies ${ }^{23}$

\section{$5 \quad$ Results}

Tables 1 and 2 show results for females and males respectively. They report the estimated parameters for three versions of the option value model: SY, MY and CMY.

We have set the value of the discount factor $\beta$ to 0.76 (the estimate obtained by Stock and Wise 1990). Without fixing it, we obtain implausibly low estimates for $\beta$. Other relevant studies (see e.g. Danø, Ejrnaes, and Husted 2005, Burkhauser, Butler, and Gumus 2003) also fixed the value for the discount factor.

\footnotetext{
${ }^{23}$ Our data reveals that transitions to retirement through disability and rare (see also Brugiavini 1999). Transitions through mobility schemes represent about 6 percent of all transitions into retirement.
} 


\subsection{Females}

As explained in section 4 the SY model has been estimated on the 1995 wave of the WHIP data where we selected workers aged 50-60. Moreover, following the literature, we assume that $\rho=1$. The estimate of $\kappa(0.94)$ suggests that female employees are work-lovers. However, this estimate does not differ significantly from 1. In subsection 3.2.1 it is explained that the SY model may provide inconsistent estimates because of self-selection.

In the MY model we take the same sample of workers considered in the SY model, but those who do not retire in 1995 are followed for more years until they retire or up to 2001. Notice that Stock and Wise (1990) use only 3 years, while we use 7 years. Eight outcomes are possible in our sample: retire in one of the years between 1995 and 2001, or do not retire. The period 1995-2001 includes various changes in the pension rules which have affected workers' retirement incentives. Due to these pension reforms the preference parameters are presumably estimated with higher precision.

According to the MY model the estimate of $\rho$ is equal to 0.43 (s.e. 0.06). Apparently, preference shocks are much less persistent than assumed in the SY model (where $\rho=1$ ). At the same time, the MY estimate for $\kappa(1.76)$ is much larger than the corresponding SY estimate (0.94). Moreover, from an economic viewpoint, the MY estimate of $\kappa$ is more plausible (i.e. significantly larger than 1).

The MY model is also estimated by Stock and Wise (1990) for males. As they pointed out themselves, their estimates may be inconsistent due to dynamic self-selection problem. We claim that, for that reason, the estimate for $\kappa$ might be biased downwards. Stock and Wise (1990) suggested a conditional probability model to correct for self-selection (see section 3.2 .3 of this paper). However, they do not estimate this model. To our knowledge this is the first empirical study which explicitly accounts for dynamic self-selection in the context of the option value model.

According to the CMY model, $\kappa$ is found to be 2.09. This parameter is very precisely estimated. The value of leisure is high for females: they evaluate $€ 1$ of income during retirement more than doubled than $€ 1$ of income while working. In other words, female workers are available to retire provided that they are given a replacement rate equal at least to 49 percent. The CMY estimate of $\kappa(2.09)$ is somewhat larger that the corresponding MY estimate (1.76). This comparison suggests that dynamic-self selection 
might be a relevant empirical issue.

The CMY estimate for $\gamma$ is found to be equal to 0.28 . Being significantly less than one, it indicates that the utility function is a concave function of earnings. Although $\gamma$ is rather low, it reveals a moderate degree of riskaversion: according to this estimate, the certainty equivalent of the lottery $€ 10,000$ with probability 0.5 and $€ 20,000$ with same probability is equal to $€ 14,382$. Few applications of the option value model to females are available in the literature. The most interesting one is Danø, Ejrnaes, and Husted (2005). By comparing our results with their results it turns out that Italian female workers evaluate leisure more than the Danish's and are more riskaverse. It has to be realized that the comparison is difficult because Danø, Ejrnaes, and Husted (2005) analyzed non-married workers, whereas we analyze the whole sample of female workers, and most of them are presumably married.

In order to check the goodness-of-fit of the CMY model, we run two parallel probit regressions without financial incentives (see also Stock and Wise 1990). In the first one, we assume that each worker has the same probability to retire. In the second one, each worker of the same age have the same probability to retire. These regressions are run on the same sample used in the CMY model. The log-likelihood values are found to be -2433 for the first model and -2333 for the second model. As shown in table 1, the corresponding value in the CMY model is much higher (-1653) indicating a much better fit. Therefore, financial incentives play a key role in the retirement choice.

Figure 3 compares actual and predicted average hazard rates by age for females. Overall, the CMY model has an excellent fit to the data. It is able to explain most of the humps at various ages. Predicted hazards are within the 99 percent confidence interval at every retirement age, except at age 60 . Cumulative retirement rates (not shown) provide a further confirmation of this result. For instance, at age 55 the actual cumulative rate is equal to 53 percent, while the predicted one is equal to 52.4. At age 60 , the model over predicts retirement probabilities, attributing to workers an average retirement rate of 76 percent. Data show instead an hazard rate equal to 50 percent. Nevertheless, this model weakness is almost irrelevant, since few females are still at work at that age.

A general test of the extent to which retirement is not determined by 
Table 1: Option value parameters estimates: females

\begin{tabular}{|c|c|c|c|}
\hline Parameter & SY & $\begin{array}{l}\text { Model } \\
\text { MY }\end{array}$ & CMY \\
\hline \multirow[t]{2}{*}{$\kappa$} & 0.938 & 1.758 & 2.087 \\
\hline & $(0.055)$ & $(0.089)$ & $(0.117)$ \\
\hline \multirow[t]{2}{*}{$\gamma$} & 0.252 & 0.317 & 0.281 \\
\hline & $(0.068)$ & $(0.051)$ & $(0.052)$ \\
\hline \multirow[t]{2}{*}{$\beta$} & $0.760^{*}$ & $0.760^{*}$ & $0.760^{*}$ \\
\hline & - & - & - \\
\hline \multirow[t]{2}{*}{$\rho$} & $1^{*}$ & 0.426 & 0.581 \\
\hline & - & $(0.058)$ & $(0.041)$ \\
\hline \multirow[t]{2}{*}{$\sigma_{\xi}$} & 1.057 & 8.859 & 5.037 \\
\hline & $(0.221)$ & $(3.078)$ & $(1.929)$ \\
\hline \multirow[t]{2}{*}{$\sigma_{\nu}$} & & 4.632 & 3.230 \\
\hline & & $(1.679)$ & $(1.139)$ \\
\hline \multicolumn{4}{|c|}{ Summary statistics } \\
\hline N.Obs. & 1341 & 5341 & $5341 / 9079$ \\
\hline N.Ind. & 1341 & 1341 & 1341 \\
\hline$-\log \mathscr{L}$ & 409.28 & 1667.14 & 1653.16 \\
\hline est.method & ML & SML & SML \\
\hline
\end{tabular}

Notes: * parameter fixed; s.e. in parenthesis; monetary values are in $€ 1,000$ (2009 euros); base year is 1995; ML is maximum likelihood, SML is simulated maximum likelihood, GHK simulator with 100 random draws plus antithetics. 
Figure 3: Hazard rates by age: females

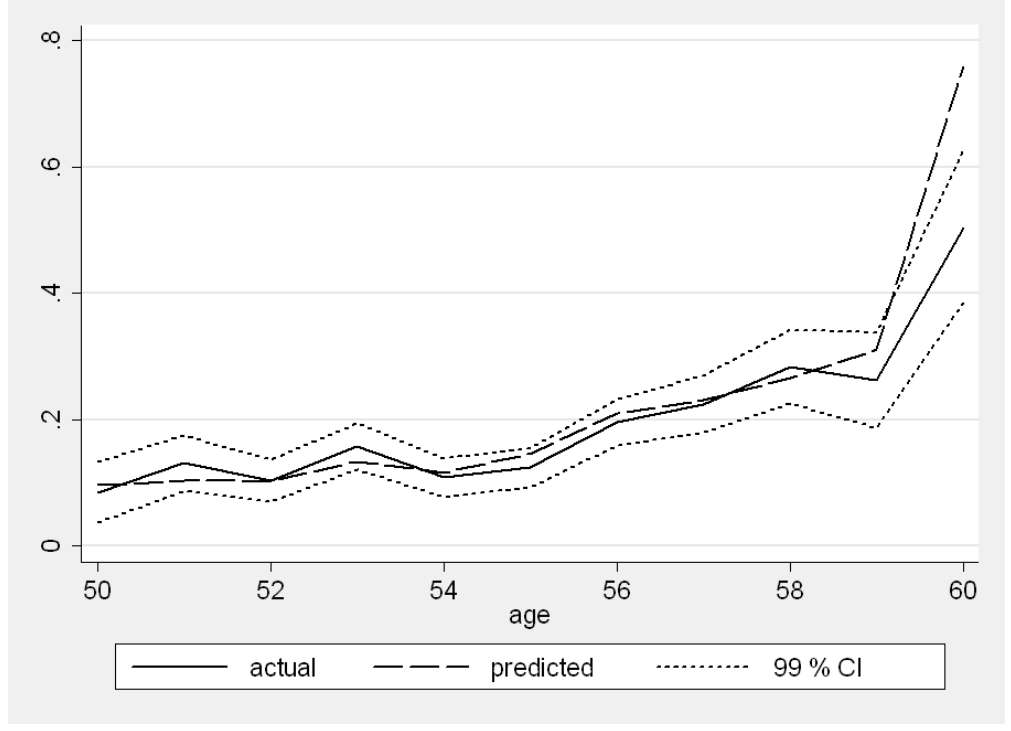

monetary variables is the gain in the fit when age is added to the model. We follow Stock and Wise and parameterize $\kappa$ as a function of age in the following way: $\kappa=\kappa_{0}(\text { age } / 50)^{\kappa_{1}}$. It appears that that the gain in the fit is small: the estimate of the parameter $\kappa_{1}$ does not differ significantly from zero at the 1 percent level. This result is in line with the findings presented in figure 3 .

\subsection{Males}

For the male sample we started out by estimating models with constant $\kappa$ as we did for females. From a first analysis it however appeared that the models fit was unsatisfactory. Therefore, we decided to allow for an age specific $\kappa$. As argued by Euwals, van Vuuren, and Wolthoff (2006), the value of leisure may rise with age due to e.g. increasing health problems ${ }^{24}$ Table 2 shows results for the specification $\kappa=\kappa_{0}(\text { age } / 50)^{\kappa_{1}}$. In all models (SY, MY, and CMY), the estimate of $\kappa_{1}$ is sizable and significantly greater than zero. Figure 4 shows for all models the strong relationship between the marginal value of leisure $(\kappa)$ and age.

In the SY model, we select workers aged 50 to 65 in year 1991. The

\footnotetext{
${ }^{24}$ At the end of the previous subsection we have seen that this argument does not seem to be relevant for females: for them we obtained an insignificant estimate for $\kappa_{1}$. One possible explanation is that females have different ("healthier") types of jobs than males.
} 
Figure 4: Estimated $\kappa$ by age, males: different models

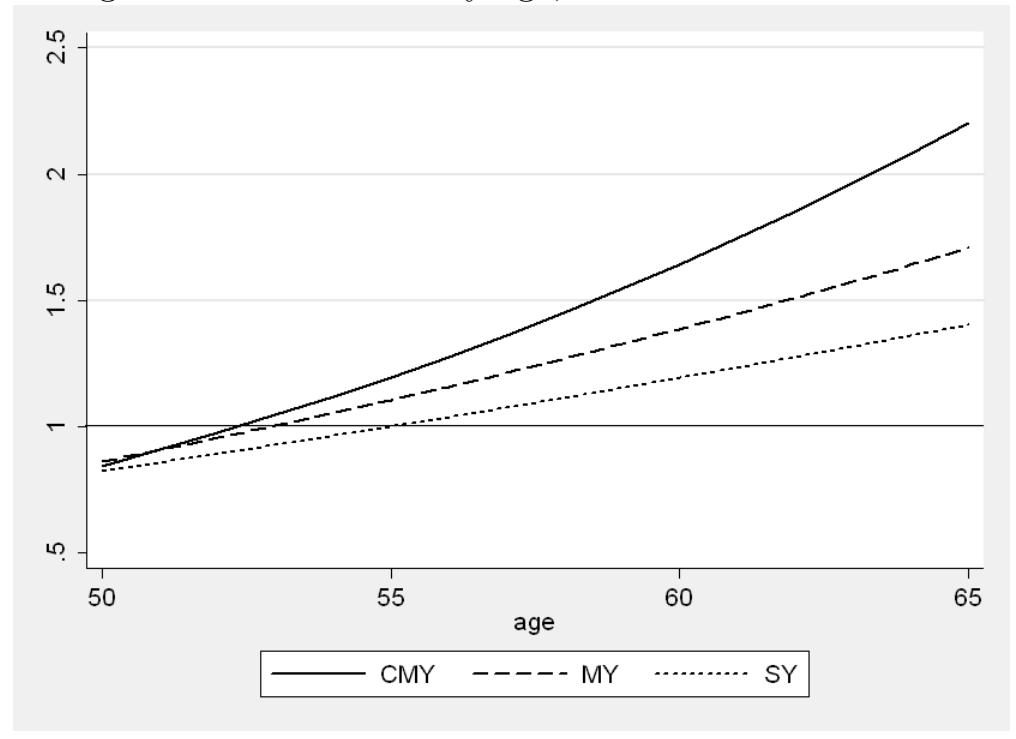

sample size is much bigger for males than for females ( 7,180 versus 1,341 workers). As for females, we assume that $\rho=1$. Results for $\kappa_{0}$ and $\kappa_{1}$ would suggest a negative value of leisure up to age 55 (See figure 4).

In the MY model, workers in the base year are followed for up to 11 years (see table 21), corresponding to 12 possible outcomes. In estimating this model, we therefore fully exploit the pension reforms of the 1990s. As in the case of females, the random walk assumption of the SY model is strongly rejected ( $\rho=0.11$, s.e. 0.03 ). The marginal value of leisure is higher than what is found in the SY model at every retirement age, see figure 4. The MY estimate for $\kappa$ is found to be significantly less than 1 only at ages 50 and 51 .

As shown in table 2, the correction for self-selection is incomplete for males since workers born in 1934 or earlier can be only observed after age 50. Consequently, the estimates of the CMY model for males have to be interpreted with caution. The comparison between MY and CMY results only give a first (underestimated) quantification of the effect of self-selection. In the CMY model, $\kappa$ is estimated to be e.g. 1.19 at age 55, 1.64 at 60 and 2.20 at age 65 . The corresponding values for the MY model are 1.10, 1.39 and 1.71. The effect of dynamic self-selection on $\kappa$ goes in the expected direction: the value of leisure is underestimated by the MY model ${ }^{25}$

\footnotetext{
${ }^{25}$ Notice that by assuming this functional form for $\kappa$, the effect of self-selection bias
} 
Table 2: Option value parameters estimates: males

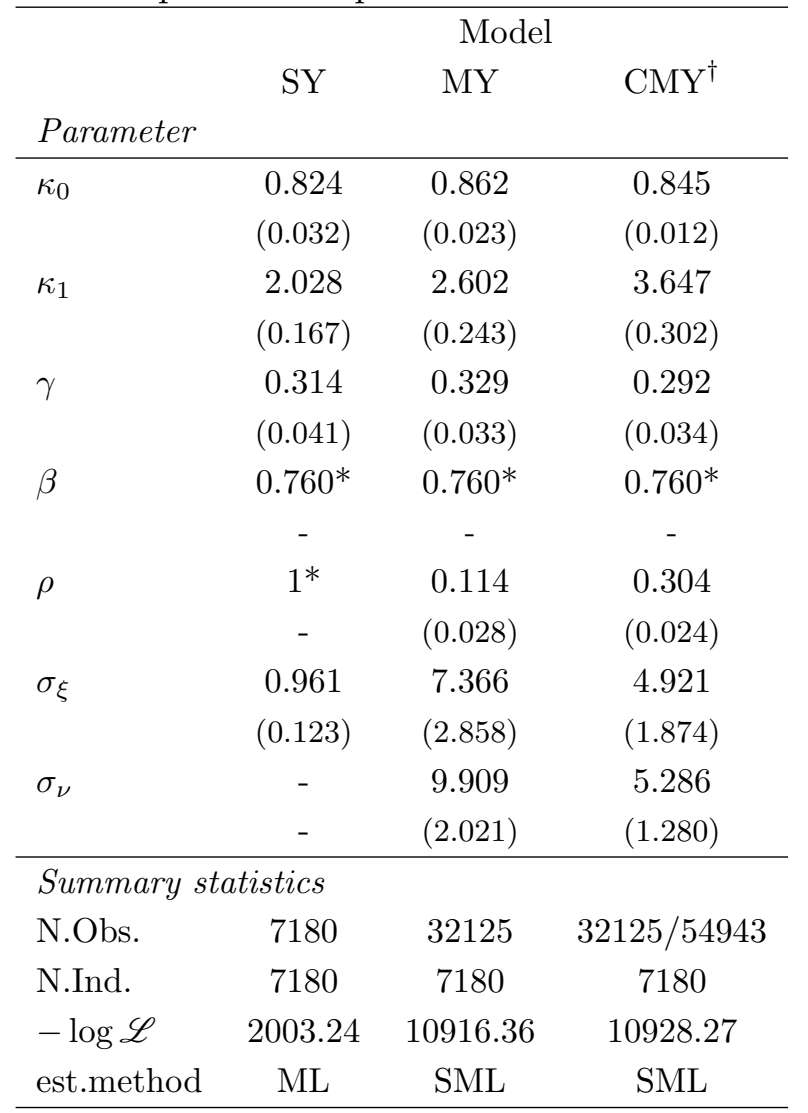

Notes: $\dagger$ only a partial correction for self-selection is possible; $*$ parameter fixed; s.e. in parenthesis; monetary values are in $€ 1,000$ (2009 euros); base year is 1991; ML is maximum likelihood, SML is simulated maximum likelihood, GHK simulator with 100 random draws plus antithetics. 
Figure 5: Hazard rates by age: males

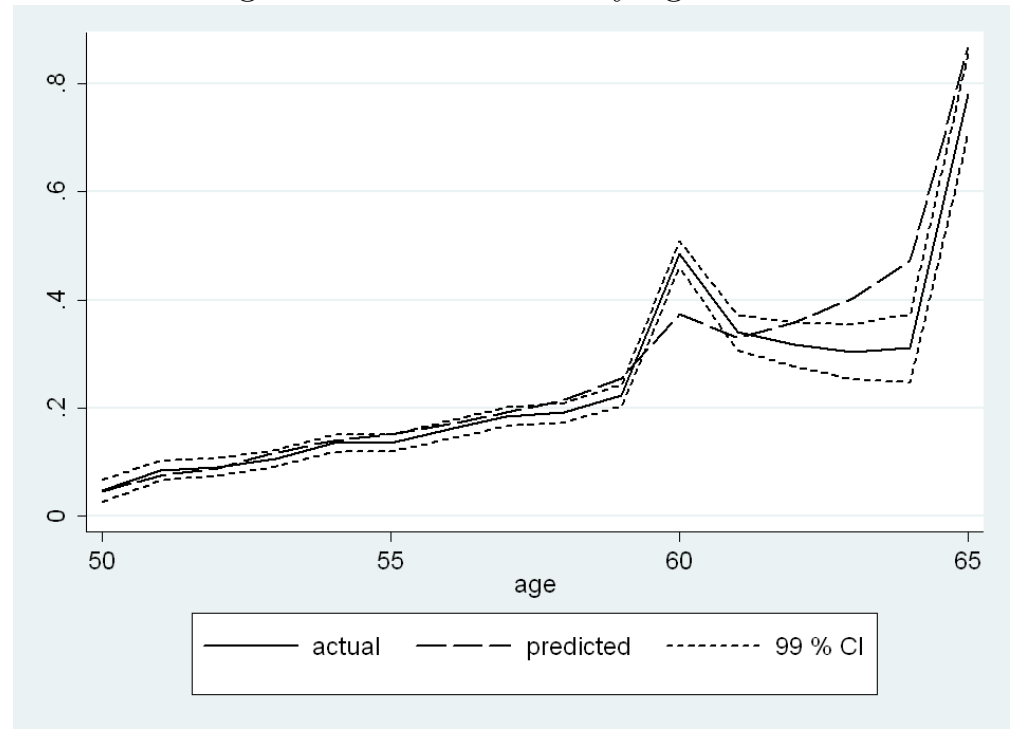

To test the CMY fit for males, we run the same two parallel regressions run for females. The log-likelihood of the model with a constant retirement probability for everyone in the sample is -16021 . The log-likelihood of the model with a constant retirement probability by age is -14739 . The log-likelihood of the CMY model is considerably lower (-10928): financial incentives strongly affect retirement choices also for males.

Figure 5 shows actual and predicted hazard rates for males. Up to age 59 , the model has a good fit. It only slightly overestimates retirement: the actual cumulative retirement rate at age 55 is equal to 46.9 , while the model predicts 48.2. At age 59 the corresponding values are 77.2 and 79.6. At higher ages the model fit is sensibly worse. In particular, the OV model heavily underestimates the spike of exits at age 60: the data show an hazard equal to 48.5 percent, while the model predicts 37 percent. Spikes of exits at typical retirement ages are a common finding in the retirement literature (see e.g. Gruber and Wise 2004a). Most of the models which quantify the impact on retirement of financial incentives either completely or partly fail to capture them (see applications in Gruber and Wise 2004b). An underes-

(i.e. the difference between the estimated $\kappa$ 's in the MY and CMY models at the same age) is increasing with age. This is coherent with the model: especially older workers who are work-lovers are included in the sample; the sample is less selected at younger ages. Obviously, the estimates of $\kappa$ at age 50 are rather close to each other. 
timation of spikes of exits is often explained by the existence of "customary age effects" (see e.g. Stock and Wise 1990). Finally, hazards at ages 62 and above are overestimated, but this is less important since they apply to a low number of workers (the cumulative retirement rate at age 61 is equal to 92 percent).

\subsection{Evaluation of a hypothetical pension reform: a simula- tion}

In this section, we exploit the estimated models (MY and CMY) to simulate the impact on retirement of a hypothetical pension reform. This reform is taken from Gruber and Wise (2004b) ${ }^{26}$ The new system sets the early retirement age at age 60 and the normal retirement age at 65 . The replacement rate at age 65 is equal to 60 percent of the earnings at age 60 . Finally, the pension benefit is reduced by 6 percent for each retirement age before 65 and increased by the same percentage for each retirement age after age 65.

In comparison with the legislation actually implemented in the sample period, this reform would introduce a more actuarially fair pension formula: as already said in section 2, actual rules grant a return of 2 percent for each additional year of work providing a strong incentive to early retirement. Moreover, for most of the workers in the sample, this reform would increase the minimum age at which they become eligible for pension benefits.

For the simulations we have constructed a "simulation sample" in the same way as Brugiavini and Peracchi (2004). In the simulation sample we consider the same workers which were present in the estimation sample but we abstract from their actual retirement choices, i.e. we allow for everyone to keep on working up to age 70 . We use the estimated wage model 22,23 , to predict workers' future wages after their actual retirement age. Using the simulation sample we then predict workers' retirement probabilities under both the actual (baseline) and the simulated legislation.

Figure 6 shows the cumulative retirement rates for females. The reform seems to have a strong impact on their retirement choices: according to the CMY model, the cumulative retirement rate at e.g. age 55 is equal to 0.61 in the baseline and to 0.20 in the simulated scenario. Due to the reform, females average retirement age increases by 3.7 years. For males we find

\footnotetext{
${ }^{26}$ The same simulation is also run in Belloni and Alessie (2009).
} 
Figure 6: Cumulative retirement rates, females: CMY versus MY model

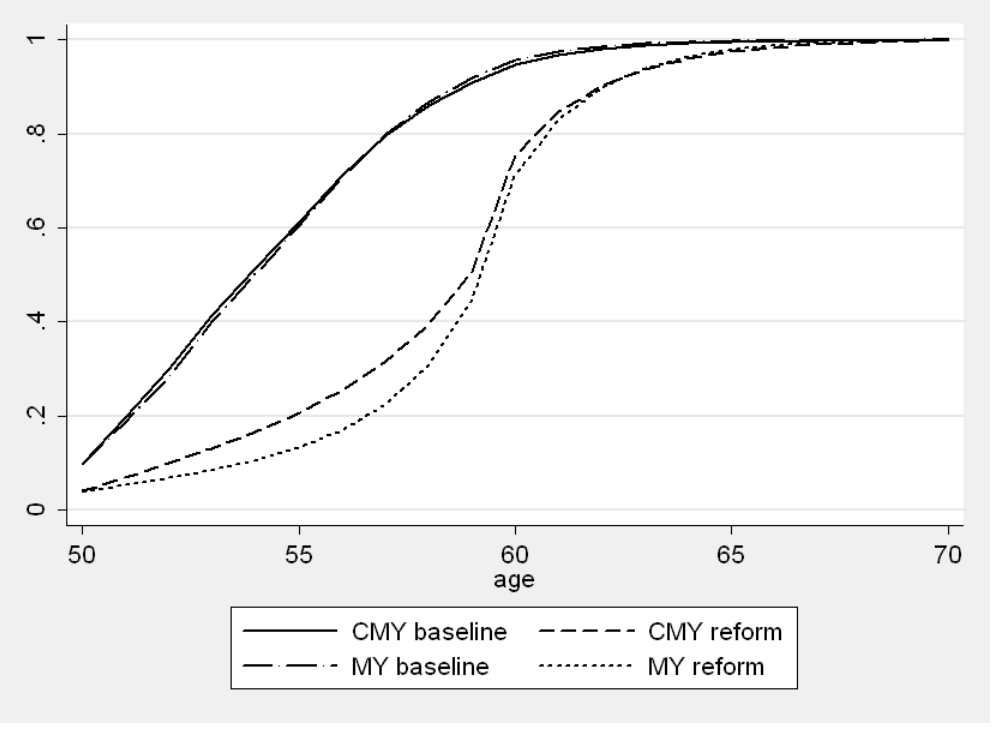

similar results: in their case the average retirement age increases by 4.2 years. More importantly, if we use the estimated MY model - instead of the CMY model - to simulate the effect of the reform on retirement we find a stronger effect. As shown in figure 6, the MY model would predict lower cumulative retirement rates with respect to the CMY model. This would result in a sizable overprediction of the impact of the reform: according to the MY model the average retirement rate for females would increase by 4.3 years, i.e. 0.6 years more than what predicted by the CMY model. Since the MY model underestimates the value of leisure, it overpredicts workers' reaction to changes in financial incentives. This simulation suggests that this bias is not negligible.

\section{Conclusions}

Using Italian administrative data this study estimates the option value model in order to quantify the effect of financial incentives of retirement choices. As far as we know, this is the first empirical analysis which estimates the conditional multiple-years model put forward by Stock and Wise (1990). This implies that we have accounted for dynamic self-selection bias. For the subsample of females the CMY model yields plausible estimates of the preference parameters such as the marginal utility of leisure. This last 
parameter is typically underestimated if one does not take into account of the self-selection problem. From a comparison of the CMY results with the MY and SY ones, it becomes clear that dynamic self-selection results in a seriously downward-biased estimate of the marginal utility of leisure. We performed a simulation study to gauge the effects of a dramatic pension reform (see subsection 5.3 for details). It turns out that the underestimation of the marginal utility of leisure translates into a sizable overprediction of the impact of the reform on retirement.

For the female sample, the model is able to predict almost perfectly the age specific hazard rates. The estimates of the CMY and MY models strongly suggest that preference shocks are much less persistent than assumed in the SY model (where full persistency is assumed). For males we also obtain estimates which are reasonably plausible. The results for males should however be interpreted with caution: for them we are not able to fully correct for dynamic self-selection bias.

One of the key assumptions of the option value model is that it does not account for savings, so that at each retirement age consumption is equal to current income. For the Italian case, this is indeed a strong assumption. According to Brugiavini and Padula (2001), discretionary saving is positive at all ages. Obviously, saving and retirement choices are interrelated. It would therefore be important to use Italian data to estimate a structural retirement model which takes saving behavior into account (see e.g. French 2005). 


\section{References}

Belloni, M., And R. Alessie (2009): "The importance of financial incentives on retirement choices: New evidence for Italy," Labour Economics, $16(5), 578-588$.

Bottazzi, R., T. Jappelli, and M. Padula (2006): "Retirement expectations, pension reforms, and their impact on private wealth accumulation," Journal of Public Economics, 90, 2187-2212.

Brugiavini, A. (1999): "Social Security and Retirement in Italy," in Social Security and Retirement Around the World, ed. by J. Gruber, and D. Wise, NBER, chap. 5, pp. 181-237. The University of Chicago Press, Chicago and London.

Brugiavini, A., and V. Galasso (2004): "The Social Security Reform Process in Italy: Where Do We Stand?," Journal of Pension Economics and Finance, 3(2), 165-195.

Brugiavini, A., And M. Padula (2001): "Too much for retirement? Saving in Italy," Research in Economics, 55, 39-60.

Brugiavini, A., and F. Peracchi (2003): "Social Security Wealth and Retirement Decisions in Italy," Labour, 17, 79-114.

(2004): "Micro-Modeling of Retirement Behavior in Italy," in Social Security Programs and Retirement Around the World: Micro-Estimation, ed. by J. Gruber, and D. Wise, NBER, chap. 6, pp. 345-398. The University of Chicago Press, Chicago and London.

Burkhauser, R., J. Butler, and G. Gumus (2003): "Option Value and Dynamic Programming Model Estimates of Social Security Disability Insurance Application Timing," IZA Discussion Paper n. 941.

(2004): "Dynamic Programming Model Estimates of Social Security Disability Insurance Application Timing," Journal of Applied Econometrics, 19(6), 671-685.

Chan, S., And A. H. Stevens (2004): "Do changes in pension incentives affect retirement? A longitudinal study of subjective retirement expectations," Journal of Public Economics, (88), 1307-1333. 
Colombino, U. (2001): "Intertemporal Interpretation of a 'Static' Model of Retirement. An exercise with Italian Data," CHILD Working Paper n. 18.

Colombino, U., E. Hermaes, Z. Jia, and S. Strom (2002): "Retirement in Italy and Norway," CHILD Working Paper n. 22.

Danø, A. M., M. Ejrnaes, And L. Husted (2005): "Do single women value early retirement more than single men?," Labour Economics, 12, $47-71$.

Deaton, A., and C. Paxson (1994): "Saving, Growth and Aging in Taiwan," in Studies in the Economics of Aging, ed. by D. Wise, pp. 331-357. University of Chicago Press.

Euwals, R., D. J. van Vuuren, and R. P. Wolthoff (2006): "Early Retirement Behaviour in the Netherlands: Evidence from a Policy Reform," Tinbergen Institute Discussion Paper n. 06-021/3.

Fornero, E., and O. Castellino (2001): La Riforma del Sistema Previdenziale Italiano. Il Mulino, Bologna.

French, E. (2005): "The Effects of Health, Wealth, and Wages on Labour Supply and Retirement Behaviour," Review of Economic Studies, 2(72), 395-427.

Gruber, J., And D. Wise (1999): Social Security and Retirement Around the World, NBER. The University of Chicago Press, Chicago and London. (2004a): "Introduction and summary," in Social Security Programs and Retirement Around the World: Micro-Estimation, ed. by J. Gruber, and D. Wise, NBER, pp. 1-40. The University of Chicago Press, Chicago and London.

- (2004b): Social Security Programs and Retirement Around the World: Micro-Estimation, NBER. The University of Chicago Press, Chicago and London.

Hajivassiliou, V. (2000): "Simulation-Based inference in econometrics: Methods and Applications," in Some practical issues in maximum simulated likelihood, ed. by R. Mariano, T. Schuermann, and M. Weeks. Cambridge University Press, Cambridge. 
Hajivassiliou, V., D. McFadden, and P. Ruud (1996): "Simulation of Multivariate Normal Rectangle Probabilities and their Derivatives: Theoretical and Computational results," Journal of Econometrics, 72, :85-134.

HARris, A. (2001): "The Effects of Social Security on Retirement Behavior: A Test of the Option-Value Model Using the Health and Retirement Study," Congressional Budget Office unpublished manuscript.

Heyma, A. (2004): "A Structural Dynamic Analysis of Retirement Behaviour in The Netherlands," Journal of Applied Econometrics, 19(6), 739-759.

Hurd, M., D. Loughran, and C. Panis (2003): "The Effects of Raising the Social Security Retirement Ages on Retirement and Disability," paper presented at the CEBR conference 'Social Security, Labour Supply and Demographic Change'.

INPS (2009): "Osservatorio sulle pensioni - www.inps.it," .

ISTAT (2008): "Tavole di Mortalità della popolazione italiana per provincia e regione di residenza," http://demo.istat.it/.

LuCAs, R. (1976): "Econometric Policy Evaluation: A Critique," CarnegieRochester Conference Series on Public Policy, 1, 19-46.

Lumsdaine, R., J. Stock, and D. Wise (1992): "Three Models of Retirement: Computational Ccomplexity Versus Predictive Validity," in Topics in the Economics of Aging, ed. by D. Wise. University of Chicago Press, Chicago and London.

(1995): "Why are Retirement Rates so High at Age 65?," NBER Working Paper n. 5190.

Spataro, L. (2000a): "The Choice of Retiring in Italy: an Application (and Extension) of the Option Value Model," University of Pisa, Economics Dep. wp n. 59.

(2000b): "Le Scelte di Pensionamento in Italia: un'Applicazione (ed Estensione) del Modello di "Option Value"," Studi Economici, 72, $25-54$. 
Stock, J. H., And D. A. Wise (1990): "Pensions, the Option Value of Work, and Retirement," Econometrica, 58, 1151-1180. 
Our papers can be downloaded at:

http://cerp.unito.it/publications

\section{CeRP Working Paper Series}

\begin{tabular}{|c|c|c|}
\hline$N^{\circ} 1 / 00$ & Guido Menzio & Opting Out of Social Security over the Life Cycle \\
\hline $\mathrm{N}^{\circ} 2 / 00$ & $\begin{array}{l}\text { Pier Marco Ferraresi } \\
\text { Elsa Fornero }\end{array}$ & $\begin{array}{l}\text { Social Security Transition in Italy: Costs, Distorsions and (some) } \\
\text { Possible Correction }\end{array}$ \\
\hline$N^{\circ} 3 / 00$ & $\begin{array}{l}\text { Emanuele Baldacci } \\
\text { Luca Inglese }\end{array}$ & $\begin{array}{l}\text { Le caratteristiche socio economiche dei pensionati in Italia. } \\
\text { Analisi della distribuzione dei redditi da pensione (only available } \\
\text { in the Italian version) }\end{array}$ \\
\hline$N^{\circ} 4 / 01$ & Peter Diamond & Towards an Optimal Social Security Design \\
\hline$N^{\circ} 5 / 01$ & Vincenzo Andrietti & $\begin{array}{l}\text { Occupational Pensions and Interfirm Job Mobility in the } \\
\text { European Union. Evidence from the ECHP Survey }\end{array}$ \\
\hline$N^{\circ} 6 / 01$ & Flavia Coda Moscarola & $\begin{array}{l}\text { The Effects of Immigration Inflows on the Sustainability of the } \\
\text { Italian Welfare State }\end{array}$ \\
\hline $\mathrm{N}^{\circ} 7 / 01$ & Margherita Borella & $\begin{array}{l}\text { The Error Structure of Earnings: an Analysis on Italian } \\
\text { Longitudinal Data }\end{array}$ \\
\hline $\mathrm{N}^{\circ} 8 / 01$ & Margherita Borella & $\begin{array}{l}\text { Social Security Systems and the Distribution of Income: an } \\
\text { Application to the Italian Case }\end{array}$ \\
\hline$N^{\circ} 9 / 01$ & Hans Blommestein & $\begin{array}{l}\text { Ageing, Pension Reform, and Financial Market Implications in } \\
\text { the OECD Area }\end{array}$ \\
\hline$N^{\circ} 10 / 01$ & $\begin{array}{l}\text { Vincenzo Andrietti and Vincent } \\
\text { Hildebrand }\end{array}$ & $\begin{array}{l}\text { Pension Portability and Labour Mobility in the United States. } \\
\text { New Evidence from the SIPP Data }\end{array}$ \\
\hline $\mathrm{N}^{\circ} 11 / 01$ & $\begin{array}{l}\text { Mara Faccio and Ameziane } \\
\text { Lasfer }\end{array}$ & $\begin{array}{l}\text { Institutional Shareholders and Corporate Governance: The Case } \\
\text { of UK Pension Funds }\end{array}$ \\
\hline $\mathrm{N}^{\circ} 12 / 01$ & Roberta Romano & $\begin{array}{l}\text { Less is More: Making Shareholder Activism a Valuable } \\
\text { Mechanism of Corporate Governance }\end{array}$ \\
\hline $\mathrm{N}^{\circ} 13 / 01$ & Michela Scatigna & Institutional Investors, Corporate Governance and Pension Funds \\
\hline$N^{\circ} 14 / 01$ & Thomas H. Noe & Investor Activism and Financial Market Structure \\
\hline $\mathrm{N}^{\circ} 15 / 01$ & Estelle James & $\begin{array}{l}\text { How Can China Solve ist Old Age Security Problem? The } \\
\text { Interaction Between Pension, SOE and Financial Market Reform }\end{array}$ \\
\hline$N^{\circ} 16 / 01$ & $\begin{array}{l}\text { Estelle James and } \\
\text { Xue Song }\end{array}$ & $\begin{array}{l}\text { Annuities Markets Around the World: Money's Worth and Risk } \\
\text { Intermediation }\end{array}$ \\
\hline$N^{\circ} 17 / 02$ & $\begin{array}{l}\text { Richard Disney and } \\
\text { Sarah Smith }\end{array}$ & $\begin{array}{l}\text { The Labour Supply Effect of the Abolition of the Earnings Rule } \\
\text { for Older Workers in the United Kingdom }\end{array}$ \\
\hline$N^{\circ} 18 / 02$ & Francesco Daveri & $\begin{array}{l}\text { Labor Taxes and Unemployment: a Survey of the Aggregate } \\
\text { Evidence }\end{array}$ \\
\hline$N^{\circ} 19 / 02$ & $\begin{array}{l}\text { Paolo Battocchio } \\
\text { Francesco Menoncin }\end{array}$ & $\begin{array}{l}\text { Optimal Portfolio Strategies with Stochastic Wage Income and } \\
\text { Inflation: The Case of a Defined Contribution Pension Plan }\end{array}$ \\
\hline$N^{\circ} 20 / 02$ & Mauro Mastrogiacomo & Dual Retirement in Italy and Expectations \\
\hline $\mathrm{N}^{\circ} 21 / 02$ & $\begin{array}{l}\text { Olivia S. Mitchell } \\
\text { David McCarthy }\end{array}$ & Annuities for an Ageing World \\
\hline
\end{tabular}




\begin{tabular}{|c|c|}
\hline$N^{\circ} 22 / 02$ & $\begin{array}{l}\text { Chris Soares } \\
\text { Mark Warshawsky }\end{array}$ \\
\hline$N^{\circ} 23 / 02$ & Ermanno Pitacco \\
\hline $\mathrm{N}^{\circ} 24 / 02$ & $\begin{array}{l}\text { Laura Ballotta } \\
\text { Steven Haberman }\end{array}$ \\
\hline $\mathrm{N}^{\circ} 25 / 02$ & $\begin{array}{l}\text { Edmund Cannon } \\
\text { Ian Tonks }\end{array}$ \\
\hline $\mathrm{N}^{\circ} 26 / 02$ & E. Philip Davis \\
\hline $\mathrm{N}^{\circ} 27 / 02$ & Reinhold Schnabel \\
\hline$N^{\circ} 28 / 02$ & Luca Spataro \\
\hline $\mathrm{N}^{\circ} 29 / 02$ & Marco Taboga \\
\hline$N^{\circ} 30 / 03$ & $\begin{array}{l}\text { Bas Arts } \\
\text { Elena Vigna }\end{array}$ \\
\hline$N^{\circ} 31 / 03$ & Giacomo Ponzetto \\
\hline $\mathrm{N}^{\circ} 32 / 04$ & $\begin{array}{l}\text { Angelo Marano } \\
\text { Paolo Sestito }\end{array}$ \\
\hline$N^{\circ} 33 / 04$ & $\begin{array}{l}\text { Elsa Fornero } \\
\text { Carolina Fugazza } \\
\text { Giacomo Ponzetto }\end{array}$ \\
\hline$N^{\circ} 34 / 04$ & Chourouk Houssi \\
\hline$N^{\circ} 35 / 04$ & $\begin{array}{l}\text { Monika Bütler } \\
\text { Olivia Huguenin } \\
\text { Federica Teppa }\end{array}$ \\
\hline$N^{\circ} 36 / 04$ & Laurence J. Kotlikoff \\
\hline $\mathrm{N}^{\circ} 37 / 04$ & Jay Ginn \\
\hline$N^{\circ} 38 / 05$ & $\begin{array}{l}\text { Carolina Fugazza } \\
\text { Federica Teppa }\end{array}$ \\
\hline$N^{\circ} 39 / 05$ & Anna Rita Bacinello \\
\hline $\mathrm{N}^{\circ} 40 / 05$ & $\begin{array}{l}\text { Carolina Fugazza } \\
\text { Massimo Guidolin } \\
\text { Giovanna Nicodano }\end{array}$ \\
\hline$N^{\circ} 41 / 05$ & $\begin{array}{l}\text { Massimo Guidolin } \\
\text { Giovanna Nicodano }\end{array}$ \\
\hline $\mathrm{N}^{\circ} 42 / 05$ & $\begin{array}{l}\text { Margherita Borella } \\
\text { Flavia Coda Moscarola }\end{array}$ \\
\hline$N^{\circ} 43 / 05$ & $\begin{array}{l}\text { John Beshears } \\
\text { James J. Choi } \\
\text { David Laibson } \\
\text { Brigitte C. Madrian }\end{array}$ \\
\hline
\end{tabular}

Annuity Risk: Volatility and Inflation Exposure in Payments from Immediate Life Annuities

Longevity Risk in Living Benefits

Valuation of Guaranteed Annuity Conversion Options

The Behaviour of UK Annuity Prices from 1972 to the Present

Issues in the Regulation of Annuities Markets

Annuities in Germany before and after the Pension Reform of 2001

New Tools in Micromodeling Retirement Decisions: Overview and Applications to the Italian Case

The Realized Equity Premium has been Higher than Expected: Further Evidence

A Switch Criterion for Defined Contribution Pension Schemes

Risk Aversion and the Utility of Annuities

Older Workers and Pensioners: the Challenge of Ageing on the Italian Public Pension System and Labour Market

A Comparative Analysis of the Costs of Italian Individual Pension Plans

Le Vieillissement Démographique :

Problématique des Régimes de Pension en Tunisie

What Triggers Early Retirement. Results from Swiss Pension Funds

Pensions Systems and the Intergenerational Distribution of Resources

Actuarial Fairness or Social Justice?

A Gender Perspective on Redistribution in Pension Systems

An Empirical Assessment of the Italian Severance Payment (TFR)

Modelling the Surrender Conditions in Equity-Linked Life Insurance

Investing for the Long-Run in European Real Estate. Does Predictability Matter?

Small Caps in International Equity Portfolios: The Effects of Variance Risk.

Distributive Properties of Pensions Systems: a Simulation of the Italian Transition from Defined Benefit to Defined Contribution The Importance of Default Options for Retirement Saving Outcomes: Evidence from the United States 


\begin{tabular}{|c|c|}
\hline$N^{\circ} 44 / 05$ & Henrik Cronqvist \\
\hline$N^{\circ} 45 / 05$ & Claudio Campanale \\
\hline$N^{\circ} 46 / 05$ & $\begin{array}{l}\text { Annamaria Lusardi } \\
\text { Olivia S. Mitchell }\end{array}$ \\
\hline$N^{\circ} 47 / 06$ & $\begin{array}{l}\text { Michele Belloni } \\
\text { Carlo Maccheroni }\end{array}$ \\
\hline$N^{\circ} 48 / 06$ & $\begin{array}{l}\text { Onorato Castellino } \\
\text { Elsa Fornero }\end{array}$ \\
\hline$N^{\circ} 49 / 06$ & Mariacristina Rossi \\
\hline$N^{\circ} 50 / 06$ & $\begin{array}{l}\text { Andrea Buffa } \\
\text { Chiara Monticone }\end{array}$ \\
\hline$N^{\circ} 51 / 06$ & Giovanni Mastrobuoni \\
\hline$N^{\circ} 52 / 06$ & $\begin{array}{l}\text { Luigi Guiso } \\
\text { Tullio Jappelli }\end{array}$ \\
\hline$N^{\circ} 53 / 06$ & Giovanni Mastrobuoni \\
\hline$N^{\circ} 54 / 06$ & $\begin{array}{l}\text { Annamaria Lusardi } \\
\text { Olivia S. Mitchell }\end{array}$ \\
\hline$N^{\circ} 55 / 06$ & Antonio Abatemarco \\
\hline$N^{\circ} 56 / 07$ & $\begin{array}{l}\text { John A. Turner } \\
\text { Satyendra Verma }\end{array}$ \\
\hline$N^{\circ} 57 / 07$ & $\begin{array}{l}\text { Giovanni Mastrobuoni } \\
\text { Matthew Weinberg }\end{array}$ \\
\hline$N^{\circ} 58 / 07$ & $\begin{array}{l}\text { Elisa Luciano } \\
\text { Jaap Spreeuw } \\
\text { Elena Vigna }\end{array}$ \\
\hline$N^{\circ} 59 / 07$ & $\begin{array}{l}\text { Riccardo Calcagno } \\
\text { Roman Kraeussl } \\
\text { Chiara Monticone }\end{array}$ \\
\hline $\mathrm{N}^{\circ} 60 / 07$ & $\begin{array}{l}\text { Riccardo Cesari } \\
\text { Giuseppe Grande } \\
\text { Fabio Panetta }\end{array}$ \\
\hline $\mathrm{N}^{\circ} 61 / 07$ & Irina Kovrova \\
\hline$N^{\circ} 62 / 07$ & $\begin{array}{l}\text { Margherita Borella } \\
\text { Elsa Fornero } \\
\text { Mariacristina Rossi }\end{array}$ \\
\hline$N^{\circ} 63 / 07$ & Claudio Campanale \\
\hline$N^{\circ} 64 / 07$ & $\begin{array}{l}\text { Carlo Casarosa } \\
\text { Luca Spataro }\end{array}$ \\
\hline$N^{\circ} 65 / 07$ & Annamaria Lusardi \\
\hline
\end{tabular}

Advertising and Portfolio Choice

Increasing Returns to Savings and Wealth Inequality

Financial Literacy and Planning: Implications for Retirement Wellbeing

Actuarial Neutrality when Longevity Increases: An Application to the Italian Pension System

Public Policy and the Transition to Private Pension Provision in the United States and Europe

Examining the Interaction between Saving and Contributions to Personal Pension Plans. Evidence from the BHPS

Do European Pension Reforms Improve the Adequacy of Saving?

The Social Security Earnings Test Removal. Money Saved or Money Spent by the Trust Fund?

Information Acquisition and Portfolio Performance

Labor Supply Effects of the Recent Social Security Benefit Cuts: Empirical Estimates Using Cohort Discontinuities

Baby Boomer Retirement Security: The Roles of Planning, Financial Literacy, and Housing Wealth

On the Measurement of Intra-Generational Lifetime Redistribution in Pension Systems

Why Some Workers Don’t Take 401(k) Plan Offers: Inertia versus Economics

Heterogeneity in Intra-Monthly Consumption. Patterns, SelfControl, and Savings at Retirement

Modelling Stochastic Mortality for Dependent Lives

An Analysis of the Effects of the Severance Pay Reform on Credit to Italian SMEs

La Previdenza Complementare in Italia:

Caratteristiche, Sviluppo e Opportunità per i Lavoratori

Effects of the Introduction of a Funded Pillar on the Russian Household Savings: Evidence from the 2002 Pension Reform

Does Consumption Respond to Predicted Increases in Cash-onhand Availability? Evidence from the Italian "Severance Pay"

Life-Cycle Portfolio Choice: The Role of Heterogeneous UnderDiversification

Rate of Growth of Population, Saving and Wealth in the Basic Life-cycle Model when the Household is the Decision Unit

Household Saving Behavior: The Role of Literacy, Information and Financial Education Programs

(Updated version June 08: “Financial Literacy: An Essential Tool for Informed Consumer Choice?”) 


\begin{tabular}{|c|c|}
\hline$N^{\circ} 66 / 07$ & $\begin{array}{l}\text { Maarten van Rooij } \\
\text { Annamaria Lusardi } \\
\text { Rob Alessie }\end{array}$ \\
\hline$N^{\circ} 67 / 07$ & $\begin{array}{l}\text { Carolina Fugazza } \\
\text { Maela Giofré } \\
\text { Giovanna Nicodano }\end{array}$ \\
\hline$N^{\circ} 68 / 07$ & $\begin{array}{l}\text { Massimo Guidolin } \\
\text { Giovanna Nicodano }\end{array}$ \\
\hline $\mathrm{N}^{\circ} 69 / 07$ & $\begin{array}{l}\text { Carolina Fugazza } \\
\text { Massimo Guidolin } \\
\text { Giovanna Nicodano }\end{array}$ \\
\hline $\mathrm{N}^{\circ} 70 / 07$ & $\begin{array}{l}\text { Radha Iyengar } \\
\text { Giovanni Mastrobuoni }\end{array}$ \\
\hline $\mathrm{N}^{\circ} 71 / 07$ & Flavia Coda Moscarola \\
\hline $\mathrm{N}^{\circ} 72 / 08$ & $\begin{array}{l}\text { Annamaria Lusardi } \\
\text { Olivia Mitchell }\end{array}$ \\
\hline$N^{\circ} 73 / 08$ & $\begin{array}{l}\text { Michele Belloni } \\
\text { Rob Alessie }\end{array}$ \\
\hline$N^{\circ} 74 / 08$ & Maela Giofré \\
\hline $\mathrm{N}^{\circ} 75 / 08$ & $\begin{array}{l}\text { Harold Alderman } \\
\text { Johannes Hoogeveen } \\
\text { Mariacristina Rossi }\end{array}$ \\
\hline$N^{\circ} 76 / 08$ & $\begin{array}{l}\text { Riccardo Calcagno } \\
\text { Elsa Fornero } \\
\text { Mariacristina Rossi }\end{array}$ \\
\hline$N^{\circ} 77 / 08$ & $\begin{array}{l}\text { Giovanni Guazzarotti } \\
\text { Pietro Tommasino }\end{array}$ \\
\hline $\mathrm{N}^{\circ} 78 / 08$ & $\begin{array}{l}\text { Margherita Borella } \\
\text { Giovanna Segre }\end{array}$ \\
\hline$N^{\circ} 79 / 08$ & Annamaria Lusardi \\
\hline $\mathrm{N}^{\circ} 80 / 08$ & Claudio Campanale \\
\hline $\mathrm{N}^{\circ} 81 / 09$ & $\begin{array}{l}\text { Fabio Bagliano } \\
\text { Claudio Morana }\end{array}$ \\
\hline$N^{\circ} 82 / 09$ & $\begin{array}{l}\text { Carolina Fugazza } \\
\text { Massimo Guidolin } \\
\text { Giovanna Nicodano }\end{array}$ \\
\hline$N^{\circ} 83 / 09$ & $\begin{array}{l}\text { Annamaria Lusardi } \\
\text { Peter Tufano }\end{array}$ \\
\hline$N^{\circ} 84 / 09$ & Luca Spataro \\
\hline$N^{\circ} 85 / 09$ & $\begin{array}{l}\text { Cathal O’Donoghue } \\
\text { John Lennon } \\
\text { Stephen Hynes }\end{array}$ \\
\hline
\end{tabular}

Financial Literacy and Stock Market Participation

International Diversification and Labor Income Risk

Small Caps in International Diversified Portfolios

Investing in Mixed Asset Portfolios: the Ex-Post Performance

The Political Economy of the Disability Insurance. Theory and Evidence of Gubernatorial Learning from Social Security Administration Monitoring

Women participation and caring decisions: do different institutional frameworks matter? A comparison between Italy and The Netherlands

Planning and Financial Literacy: How Do Women Fare?

The Importance of Financial Incentives on Retirement Choices: New Evidence for Italy

Information Asymmetries and Foreign Equity Portfolios: Households versus Financial Investors

Preschool Nutrition and Subsequent Schooling Attainment: Longitudinal Evidence from Tanzania

The Effect of House Prices on Household Saving: The Case of Italy

The Annuity Market in an Evolving Pension System: Lessons from Italy

Le pensioni dei lavoratori parasubordinati: prospettive dopo un decennio di gestione separata

Increasing the Effectiveness of Financial Education in the Workplace

Learning, Ambiguity and Life-Cycle Portfolio Allocation

Permanent and Transitory Dynamics in House Prices and Consumption: Cross-Country Evidence

Time and Risk Diversification in Real Estate Investments: Assessing the Ex Post Economic Value

Debt Literacy, Financial Experiences, and Overindebtedness

Il sistema previdenziale italiano dallo shock petrolifero del 1973 al Trattato di Maastricht del 1993

The Life-Cycle Income Analysis Model (LIAM): A Study of a Flexible Dynamic Microsimulation Modelling Computing Framework 
N 86/09 Margherita Borella Flavia Coda Moscarola

№ 87/09 Elsa Fornero

Annamaria Lusardi Chiara Monticone

N 88/09 Maela Giofré

N 89/09 Elena Vigna

N 90/09 Annamaria Lusardi Olivia S. Mitchell

N 91/09 Annamaria Lusardi Olivia S. Mitchell Vilsa Curto

$N^{\circ} 92 / 10$ Michele Belloni

Microsimulation of Pension Reforms: Behavioural versus Nonbehavioural Approach

Adequacy of Saving for Old Age in Europe

Convergence of EMU Equity Portfolios

Mean-variance inefficiency of CRRA and CARA utility functions for portfolio selection in defined contribution pension schemes

How Ordinary Consumers Make Complex Economic Decisions: Financial Literacy and Retirement Readiness

Financial Literacy among the Young:

Evidence and Implications for Consumer Policy

Retirement choices in Italy: what an option value model tells us 